\title{
Phytocomponents from Anacardium occidentale, Psidium guajava, and Terminalia catappa altered membrane osmotic stability of sickle erythrocytes
}

\author{
Paul C. Chikezie ${ }^{*} \mathbb{D}$, Raphael C. Ekeanyanwu and Adaeze B. Chile-Agada
}

\begin{abstract}
Background: The present study identified, quantified, and characterized the combinations of phytocomponents from fractionated leaf extracts of Anacardium occidentale, Psidium guajava, and Terminalia catappa that stabilized sickle erythrocyte membrane against osmotic stress, or otherwise, using standard chromatographicspectrophotometric techniques, namely GC-MS, FT-IR, and UV-visible systems.

Results: The percentage hemolysis of the control sample, in $0.9 \mathrm{~g} / 100 \mathrm{~mL} \mathrm{NaCl}$, was $35.08 \pm 11.64 \%$, whereas those of the samples containing $40 \mathrm{mg} / 100 \mathrm{~mL}, 60 \mathrm{mg} / 100 \mathrm{~mL}$, and $80 \mathrm{mg} / 100 \mathrm{~mL}$ of ethylacetate extracts of T. catappa ranged between $31.82 \pm 8.32$ and $39.18 \pm 6.94 \%$. Ethylacetate extract of T. catappa contained comparative high quantities of hexadecanoic acid methyl ester, 9,11-octadecadienoic acid, methyl ester, (E, E)-, trans-13-octadecenoic acid methyl ester, and methyl stearate. FT-IR and UV-visible spectra showed that ethylacetate extract of T. catappa contained aromatic compounds as well as nitro-compounds, phenolics, and esters.

Conclusion: To mention but a few, the combinations of major phytocomponents that stabilized sickle erythrocyte membrane against osmotic stress were hexadecanoic acid, methyl ester, 11-octadecenoic acid, methyl ester, dibutyl phthalate, pentacosane, trans-13-octadecenoic acid, methyl ester, whereas the minor phytocomponents include methyl tetradecanoate, methoxyacetic acid, 3-pentadecyl ester, methyl stearate, hexadecanoic acid, isoxazole, 4,5-dimethyl-.
\end{abstract}

Keywords: Hemolysis, Mean corpuscular fragility, Osmotic stability, Phytocomponents, Sickle erythrocyte

\section{Background}

The cashew tree (Anacardium occidentale Linn.), native to tropical America, is often found growing wild in the central plains of Brazil and later cultivated in many parts of the Amazon rainforest. Stem bark, leaves, and shell oil around the nuts are used for astringent preparations and remedies against inflammatory disorders, and therefore exploited for the treatment of ulcers and diarrhea [1-3]. Although acute, sub-acute toxicity and genotoxic effects of hydro-ethanolic extract of $A$. occidentale on biologic systems have been reported, the crude extract did not produce toxic symptoms in rats in doses up to $2000 \mathrm{mg} / \mathrm{kg}$ [3]. However, the report showed that the extract induced frame-shift mutation, base-

* Correspondence: p_chikezie@yahoo.com

Department of Biochemistry, Imo State University, Owerri, Nigeria pair substitution, and chromosomal damage but the toxic effects were less deleterious than the clastogenic effect of cyclophosphamide on Swiss mice micronucleus [3]. The major bioactive principles present in leaves of $A$. occidentale are the flavonoids and tannins $[3,4]$ along with the fruit phenolic lipids that exhibit toxic effects in biologic systems $[3,5]$. The notable flavonoids present in leaves of $A$. occidentale are quercetin-3-O-rhamnoside, kaempferol-3-O-methyl-ether, myricetin-3-O-rhamnoside, kaempferol-3-O-rhamnoside, and amentoflavone [4] as well as the proanthocianidins [6]. Reports also showed that $A$. occidentale leaves are rich in phenols, phlobotannins, cyanogenic glycosides, saponins, (3E)-3,7-dimethylocta-1,3,6-triene, and (1S,6S,7S,8S)-1,3-dimethyl-8-propan-2-yltricyclo $\left[4 \cdot 4 \cdot 0.0^{2,7}\right]$ dec-3-ene $[7,8]$. 
Guava (Psidium guajava Linn.), which belongs to the Myrtaceae family, is often found in tropical and semitropical regions of the world. The leaves of P. guajava contain substantial quantity of lectin, which is why the leaf extract is used as herbal remedies for intestinal infections caused by pathogens like Escherichia coli $[9,10]$. Previous reports also showed that mature leaf extracts of $P$. guajava exhibited antimicrobial properties due to their substantial content of flavonoids, namely quercetin-3-O- $\alpha$-L-arabinofuranoside, quercetin-3-O- $\beta$-D-arabinofuranoside, quercetin-3-O- $\beta$-D-glucoside, quercetin-3-O- $\beta$-D-galactoside, and quercetin-3-O- $\beta$-D-arabinofuranoside [11] along with the presence of squalene and azulene, which are antifungals [12]. The diverse medicinal usefulness of decoctions of guava leaves has been extensively reported elsewhere [11, 13-16].

The Indian almond tree (Terminalia catappa Linn.) belongs to the Combretaceae family. Indian almond leaves contain flavonoids such as kaempferol, quercetin, and tannins. Flavonoids are protective against degenerative diseases, such as cancer, diabetes, cardiovascular diseases, and cataract [17-21]. The antioxidant phytochemicals in $T$. catappa leaves include punicalagin, punicalin, terfluvina A and $\mathrm{B}$, chebulic acid, benzoic acid, and cumaric acid and its derivatives [22]. The vast medicinal usefulness, based on empirical data and traditional medicinal practices, of leaf extracts of T. catappa are summarized elsewhere [22-24].

When erythrocytes are suspended in hypotonic sodium chloride $(\mathrm{NaCl})$ solution of diminishing osmolality, the uptake of water by the erythrocyte is both instantaneous and quantitative. In practical terms, the quantity of hemoglobin released into the hypotonic solutions following hemolysis is a measure of erythrocyte osmotic fragility index [25-27]. Accordingly, osmotic fragility index defines the capacity of the erythrocytes to withstand hemolysis when subjected to osmotic stress [27]. Osmotic fragility test, in which the population of hemolyzed erythrocytes is measured as a function of variability in osmolality of erythrocyte suspension, is primarily diagnostic of hereditary disorders of erythrocyte membrane cytoskeletal structures such as hereditary spherocytosis and other vast groups of the hemolytic anemias [27-32]. The extrinsic and intrinsic factors that influence erythrocyte osmotic fragility index are summarized elsewhere [27, 30].

Sickle cell disease (SCD) is a hereditary autosomal recessive erythrocyte disorder caused by mutant hemoglobin molecules (sickle cell hemoglobinopathy; $\alpha_{2} \beta_{2}{ }^{\mathrm{s}}$ ) that polymerize under low oxygen tension within the microvasculature. Intra-erythrocytic polymerization of deoxygenated sickle hemoglobin, in turn, promotes distortion of the erythrocytes that take up the sickle morphology [33-35]. The functional and structural defective erythrocytes elicit multiple clinical disorders, notably; severe anemia, vasoocclusion, multiple organ damage, and splenomegaly associated secondary infections [36]. The biological activities and identities of chemical constituents from medicinal plants used for the management of SCD have been exhaustively reviewed elsewhere [37, 38].

Sickle erythrocytes are relatively fragile and frequently undergo spontaneous osmotic lysis because of low elasticity and rigidity of their membrane structures [35]. The enhanced membrane fragility index is further exacerbated by high oxidative stressed status of sickle erythrocytes [39-41]. Stabilization of erythrocyte membrane structures by herbal extracts is attributable to antioxidant activities and membrane chaotropic agent antagonists of phytocomponents from diverse plants [21, 26, 42-44]. Because of limited scope of the previous investigations [21, 26, 43], the combinations of phytocomponents from the herbal extracts that stabilized the erythrocyte membrane against osmotic stress were not identified, quantified, and characterized. Spectrometric methods, viz. Fourier transform-infrared spectroscopy (FT-IR) and ultraviolet-visible spectroscopy (UV-visible) complement gas chromatography-mass spectroscopy (GC-MS) protocols in terms of providing comprehensive insights into the molecular characteristics and quantification of phytocomponents from plant materials [21, 45-49].

In view of the established relatively high fragility of sickle erythrocytes and medicinal usefulness of vast array of phytocomponents, the present study investigated the capacities of fractionated leaf extracts of $A$. occidentale, $P$. guajava, and T. catappa to stabilize sickle erythrocyte membrane against osmotic stress using in vitro models. Furthermore, the present study identified, quantified, and characterized the combinations of phytocomponents from fractionated leaf extracts of A. occidentale, P. guajava, and $T$. catappa that stabilized sickle erythrocyte membrane against osmotic stress, or otherwise, using standard chromatographic-spectrophotometric techniques, namely GC-MS, FT-IR, and UV-visible systems.

\section{Materials}

\subsection{Collection of plant materials}

Botanical gardens located within the environment that lies on Latitude $5^{\circ} 30.2237^{\prime} \mathrm{N}$; Longitude $72.6277^{\prime} \mathrm{E}$, served as sources of fresh leaves of $A$. occidentale, $P$. guajava, and T. catappa. The microclimatic conditions of the botanical gardens are summarized thus; sea-level: $73 \mathrm{~m}$, temperature range: $19.4-30{ }^{\circ} \mathrm{C}$, average annual rainfall volume: $2219 \mathrm{~mm}$, and soil type: sandy loam. The leaves were harvested between the 2nd and 7th April 2019. The leaves of the selected plants were identified and authenticated by Professor F.N. Mbagwu of the Department of Plant Science and Biotechnology, Imo State University, Owerri, Nigeria. The designated voucher numbers were as follows: A. occidentale: IMSUH 009; P. guajava: IMSUH 010; T. catappa: IMSUH 011. Samples of the plant materials were deposited in the herbarium for reference purposes. 


\section{Methods}

\subsection{Preparation, extraction, and fractionation of leaf extracts}

The preparation and extraction of the plant materials was according to the methods previously described [50]. Three hundred grams of the ground sample was subjected to repeated cycles of Soxhlet extraction protocol in $2000 \mathrm{~mL}$ of ethanol/water mixture; $1: 1 \mathrm{v} / \mathrm{v}$ for $18 \mathrm{~h}$. The hydro-ethanolic leaf extracts were fractionated according to the modified methods previously described [51]. The crude hydro-ethanolic leaf extracts were fractionated by progressive partitioning with equal volumes of solvents in the order of increasing polarities; viz. petroleum ether, $n$-hexane, chloroform, and ethylacetate.

The fractionated leaf extracts were concentrated under reduced pressure for $24 \mathrm{~h}$ at $50{ }^{\circ} \mathrm{C}$ using a rotary evaporator (Büch Rotavapor R-200). The separate residues were finally dried in anhydrous calcium chloride (desiccant) embedded desiccator. The yield of the extract per $100 \mathrm{~g}$ dry leaf sample was calculated thus:

$$
\text { Percentile yield }=\frac{\text { Weight of dried extract }}{\text { Weight of dried leaf sample }} \times 100
$$

The fractionated leaf extracts were suspended in given volumes of phosphate-buffered saline (PBS; $\mathrm{pH}=7.4$ ), osmotically equivalent to $9.0 \mathrm{~g} / \mathrm{L} \mathrm{NaCl}\{9.0 \mathrm{~g} \mathrm{NaCl}, 1.71$ g $\mathrm{Na}_{2} \mathrm{HPO}_{4} \cdot 2 \mathrm{H}_{2} \mathrm{O}$, and $2.43 \mathrm{~g} \mathrm{NaH}_{2} \mathrm{PO}_{4} \cdot 2 \mathrm{H}_{2} \mathrm{O}$ per liter to give standard solutions of the extracts used for osmotic stability studies of sickle erythrocyte membrane.

\subsection{Exclusion criteria}

Exclusion criteria for participants were according to guidelines previously proposed [52]. Participants on medications for at least 4 weeks prior to blood sampling were excluded from this study. Additionally, the collected blood samples were thoroughly checked for the presence of clot and hemolysis before used for the experiment.

\subsection{Collection and preparation of blood samples}

One hundred eight participants of HbSS genotype donated $5.0 \mathrm{~mL}$ of venous blood samples. All blood donors were consenting individuals attending clinics between the months of 7th of May and 28th of July, 2019 at Rehoboth Christian Medical Center, Nwaoruebi and Easter Summit Specialist Clinics and Maternity, Amakohia. The clinics are located in Owerri, Imo State, Nigeria. Venous peripheral blood was drawn from the forearm of participants using vacuum blood sampling disodium ethylene diamine tetraacetate (EDTA- $\mathrm{Na}_{2}$ ) tubes [52]. The confirmatory test of the blood samples was carried out using electrophoretic methods previously described [53]. The preparation of blood samples was according to previous reports [24]. The erythrocytes were finally re-suspended in $5.0 \mathrm{~mL}$ of PBS and used for osmotic stability studies of the sickle erythrocyte membrane.

\subsection{Membrane osmotic stability studies}

Erythrocyte osmotic fragility index was measured according to the method described [26]. In a total of four sets (T1-T4) of three test tubes each, $5.0 \mathrm{~mL}$ of PBS of varying concentrations equivalent to $0.9-0.3 \mathrm{~g} / 100 \mathrm{~mL}$ $\mathrm{NaCl}$ were introduced into the corresponding test tubes, such that $\mathrm{T} 1=0.9 \mathrm{~g} / 100 \mathrm{~mL}, \mathrm{~T} 2=0.6 \mathrm{~g} / 100 \mathrm{~mL}$, and $\mathrm{T} 3=0.3 \mathrm{mg} / 100 \mathrm{~mL}$. A $5.0 \mathrm{~mL}$ of distilled water was added in the fourth set of test tubes (T4). For the test analyses, $0.5 \mathrm{~mL}$ of three increasing concentrations (40 $\mathrm{mg} / 100 \mathrm{~mL}, 60 \mathrm{mg} / 100 \mathrm{~mL}$, and $80 \mathrm{mg} / 100 \mathrm{~mL}$ ) of each of the separate fractionated leaf extracts were added in different sets of test tubes in a corresponding order of concentrations of the fractionated leaf extracts. To each test tube, $0.1 \mathrm{~mL}$ of $\mathrm{HbSS}$ erythrocyte suspension $(10 \%$ hematocrit) was added and mixed thoroughly by inverting the tubes several times. For the control experiment, the same procedure was repeated but devoid of suspensions of the fractionated leaf extracts, which was replaced by PBS concentration equivalent to $0.9 \mathrm{~g} / 100 \mathrm{~mL}$ $\mathrm{NaCl}$. The erythrocyte suspensions were allowed to stand for $30 \mathrm{~min}$ at room temperature $\left(24-27^{\circ} \mathrm{C}\right.$ ) after which the contents were centrifuged at $1200 \times g$ for 10 min. The relative quantity of hemoglobin released into the supernatant was measured at $\lambda \max =540 \mathrm{~nm}$ using a spectrophotometer (Digital Blood Analyzer; SPECTRONIC 20; Labtech, LabX, Bay Street, Midland, ON, Canada). PBS concentration equivalent to $0.9 \mathrm{~g} / 100 \mathrm{~mL}$ $\mathrm{NaCl}$ served as blank.

The range of values of percentage hemolysis in PBS of varying concentrations equivalent to $0.9-0.3 \mathrm{~g} / 100 \mathrm{~mL}$ $\mathrm{NaCl}$ (T1-T3) and in distilled water (T4) were obtained by evaluating the quotient of absorbance of the content of each corresponding test tubes (T1-T3) and the fourth test tube (T4) containing distilled water and multiplied by a factor of 100 . Thus:

$$
\% \mathrm{H}_{\mathrm{T} 1-\mathrm{T} 4}=\frac{\mathrm{A}_{\mathrm{T} 1-\mathrm{T} 3}}{\mathrm{~A}_{\mathrm{T} 4}} \times 100
$$

Where;

$\% \mathrm{H}_{\mathrm{T} 1-\mathrm{T} 4}$ : range of values of percentage hemolysis (\%).

$\mathrm{A}_{\mathrm{T} 1-\mathrm{T} 3}$ : absorbance of the supernatant of erythrocyte suspension in PBS of varying concentrations equivalent to $0.9-0.3 \mathrm{~g} / 100 \mathrm{~mL} \mathrm{NaCl}$.

$\mathrm{A}_{\mathrm{T} 4}$ : absorbance of the supernatant of erythrocyte suspension in distilled water.

Note: the erythrocytes suspension in distilled water (T4) served as a $100 \%$ hemolysis point. 
The corresponding PBS concentration in $\mathrm{g} / 100 \mathrm{~mL}$ of $\mathrm{NaCl}$, which caused $50 \%$ hemolysis, was the mean corpuscular fragility (MCF) index. The MCF values were interpolated from the cumulative erythrocyte osmotic fragility curves obtained by plotting the percentage hemolysis against PBS concentrations in $\mathrm{g} / 100 \mathrm{~mL}$ of $\mathrm{NaCl}$.

The relative capacities of the fractionated leaf extracts to stabilize erythrocyte membrane were evaluated as percentage of the quotient of the difference between the MCF values of the test and control samples to that of the control sample as previously described [26]. Thus:

$$
\% \text { RMS }=\frac{\mathrm{MCF}_{\text {Control }}-\mathrm{MCF}_{\text {Test }}}{\mathrm{MCF}_{\text {Control }}} \times 100
$$

Where;

\%RMS: relative membrane stability (\%).

Note: negative value of \%RMS is indicative of destabilization by the fractionated leaf extract.

\subsection{Spectrometry}

The identification, quantification, and characterization of phytocomponents from fractionated leaf extracts of $A$. occidentale, $P$. guajava, and T. catappa were carried out using standard chromatographic-spectrophotometric protocols, viz. GC-MS systems \{Agilent 7890A GC system set up with 5975C VL MSD, Agilent Technologies, Inc., Santa Clara, CA, USA; The MS system was accomplished in Electron Ionization (EI) mode with Selected Ion Monitoring (SIM)\}as well as FT-IR and UV-visible instruments (PerkinElmer Spectrophotometer, USA) according to the methods previously described $[48,54,55]$. The capillary column specification of the GC system was DB-5MS $(30 \mathrm{~m} \times 0.25 \mathrm{~mm}$, film thickness of $0.25 \mu \mathrm{m}$ ) with a temperature program set as follows: initial temperature $50{ }^{\circ} \mathrm{C}$ held for $1.00 \mathrm{~min}, 5{ }^{\circ} \mathrm{C}$ per min to $100{ }^{\circ} \mathrm{C}, 9{ }^{\circ} \mathrm{C}$ per min to $200{ }^{\circ} \mathrm{C}$ held for $7.89 \mathrm{~min}$, and the total run time was $30 \mathrm{~min}$. The injection mode and volume were set at 20:1 and 1.0 $\mu \mathrm{L}$ respectively. The flow rate of helium as a carrier gas was set at $0.811851 \mathrm{~mL} / \mathrm{min}$. The ion source temperature and quadruple temperature of the MS system were set at $230^{\circ} \mathrm{C}$ and $150{ }^{\circ} \mathrm{C}$, respectively.

\subsection{Statistical analyses}

The data collected were expressed in means $(X) \pm \mathrm{SD}$ and analyzed in one-way ANOVA and least significance difference (LSD). The comparison was made between groups and significance was established by ANOVA at $95 \%$ confidence level. Difference of $p<0.05$ was considered statistically significant.

\section{Results}

\subsection{Percentage yields of fractionated leaf extracts}

The aggregate yields of the fractionated leaf extracts, which include petroleum ether, $n$-hexane, chloroform, ethylacetate, and residual aqueous extracts were as follows: A. occidentale (13.017 g per $100 \mathrm{~g}$ dry leaf sample), P. guajava (9.627 g per $100 \mathrm{~g}$ dry leaf sample), and $T$. catappa (10.060 g per $100 \mathrm{~g}$ dry leaf sample). However, the residual aqueous extract fractions gave relatively high yields in the following proportions: $A$. occidentale (10.20 g per $100 \mathrm{~g}$ dry leaf sample), P. guajava (7.20 g per $100 \mathrm{~g}$ dry leaf sample), and T. catappa (9.00 g per $100 \mathrm{~g}$ dry leaf sample).

\subsection{Sickle erythrocytes osmotic fragility in the presence of fractionated leaf extracts of $A$. occidentale}

Figure 1a-e showed sickle erythrocytes osmotic fragility in PBS of varying concentrations equivalent to $0.9-0.3$ $\mathrm{g} / 100 \mathrm{~mL} \mathrm{NaCl}$ in the presence of fractionated leaf extracts of $A$. occidentale. Figure 1a showed that the control sample exhibited $38.15 \pm 6.31 \%$ hemolysis in PBS concentration equivalent to $0.9 \mathrm{~g} / 100 \mathrm{~mL} \mathrm{NaCl}$, whereas $80 \mathrm{mg} / 100 \mathrm{~mL}$ petroleum ether extract of $A$. occidentale caused $73.53 \pm 10.12 \%$ hemolysis. The percentage hemolysis in the presence of $40 \mathrm{mg} / 100 \mathrm{~mL}$ petroleum ether extract of $A$. occidentale in PBS concentration equivalent to $0.9 \mathrm{~g} / 100 \mathrm{~mL} \mathrm{NaCl}$ was not significantly different $(p>0.05)$ from that of the control sample. The lowest level of percentage hemolysis in PBS concentration equivalent to $0.9 \mathrm{~g} / 100 \mathrm{~mL} \mathrm{NaCl}$ was in the presence of 60 $\mathrm{mg} / 100 \mathrm{~mL}$ ethylacetate extract of $A$. occidentale. Additionally, PBS concentration equivalent to $0.3 \mathrm{~g} / 100 \mathrm{~mL} \mathrm{NaCl}$ caused $92.98 \pm 4.45 \%$ hemolysis in the sample containing $80 \mathrm{mg} / 100 \mathrm{~mL}$ ethylacetate extract of $A$. occidentale.

Figure $1 \mathrm{~b}$ showed that in PBS concentrations equivalent to $0.6 \mathrm{~g} / 100 \mathrm{~mL}$ and $0.9 \mathrm{~g} / 100 \mathrm{~mL} \mathrm{NaCl}$, the percentage hemolysis of the control sample was not significantly different $(p>0.05)$ from those of the samples containing 40 $\mathrm{mg} / 100 \mathrm{~mL}, 60 \mathrm{mg} / 100 \mathrm{~mL}$, and $80 \mathrm{mg} / 100 \mathrm{~mL} n$-hexane extracts of $A$. occidentale. Conversely, $60 \mathrm{mg} / 100 \mathrm{~mL} n$ hexane extract of $A$. occidentale caused $75.53 \pm 14.01 \%$ hemolysis, which was significantly different $(p<0.05)$ from the control sample as well as the samples containing $40 \mathrm{mg} / 100 \mathrm{~mL}$ and $80 \mathrm{mg} / 100 \mathrm{~mL} n$-hexane extracts of $A$. occidentale.

The percentage hemolysis of the samples containing 40 $\mathrm{mg} / 100 \mathrm{~mL}, 60 \mathrm{mg} / 100 \mathrm{~mL}$, and $80 \mathrm{mg} / 100 \mathrm{~mL}$ chloroform extracts of $A$. occidentale in PBS concentrations equivalent to $0.3-0.9 \mathrm{~g} / 100 \mathrm{~mL} \mathrm{NaCl}$ were not significantly different $(p>0.05)$ from the control sample. Specifically, the percentage hemolysis of the control sample and the test samples in PBS concentration equivalent to $0.3 \mathrm{~g} /$ $100 \mathrm{~mL} \mathrm{NaCl}$ varied within a relatively narrow range of $12.22 \pm 5.82-19.60 \pm 3.43 \%$ (Fig. 1c).

The percentage hemolysis of the samples containing $40 \mathrm{mg} / 100 \mathrm{~mL}, 60 \mathrm{mg} / 100 \mathrm{~mL}$, and $80 \mathrm{mg} / 100 \mathrm{~mL}$ ethylacetate extracts of $A$. occidentale in PBS concentration equivalent to $0.9 \mathrm{~g} / 100 \mathrm{~mL} \mathrm{NaCl}$ showed no significant 

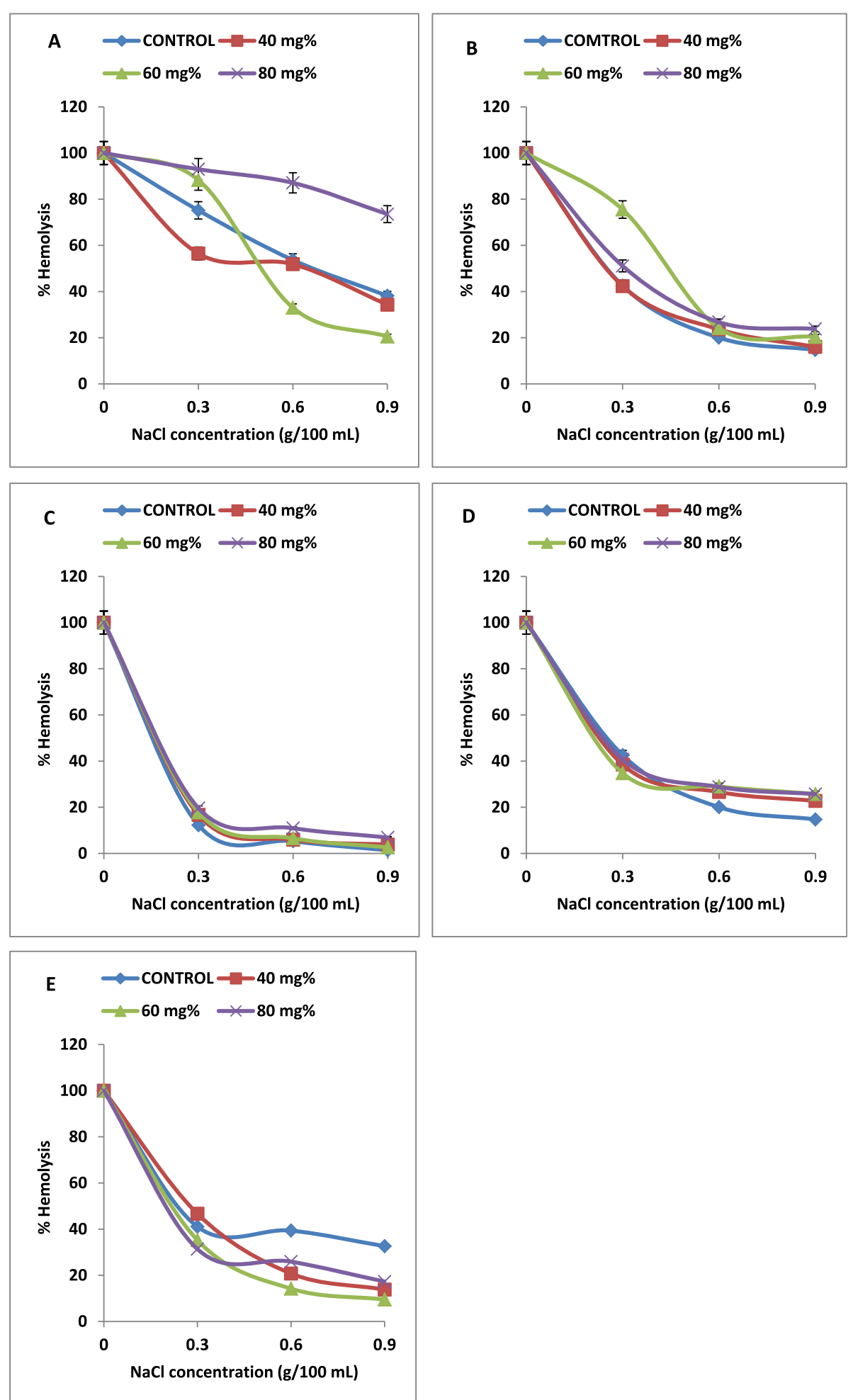

Fig. 1 Erythrocyte osmotic fragility curves: percentage hemolysis of sickle erythrocytes in PBS of varying concentrations equivalent to $0.9-0.3 \mathrm{~g} /$ $100 \mathrm{~mL} \mathrm{NaCl}$ in the presence of fractionated leaf extracts of $A$. occidentale. a Petroleum ether. $\mathbf{b} n$-hexane. $\mathbf{c}$ Chloroform. $\mathbf{d}$ Ethylacetate. e Residual aqueous 
difference $(p>0.05)$. Likewise, the percentage hemolysis of the control sample in PBS concentration equivalent to $0.3 \mathrm{~g} / 100 \mathrm{~mL} \mathrm{NaCl}$ was not significantly different $(p>$ 0.05 ) from the sample containing $80 \mathrm{mg} / 100 \mathrm{~mL}$ ethylacetate extract of $A$. occidentale (Fig. 1d).

The percentage hemolysis of the control sample in PBS concentrations equivalent to $0.6 \mathrm{~g} / 100 \mathrm{~mL}$ and 0.9 $\mathrm{g} / 100 \mathrm{~mL} \mathrm{NaCl}$ were significantly higher $(p<0.05)$ than those of samples containing $40 \mathrm{mg} / 100 \mathrm{~mL}, 60 \mathrm{mg} / 100$ $\mathrm{mL}$, and $80 \mathrm{mg} / 100 \mathrm{~mL}$ residual aqueous extracts of $A$. occidentale. Conversely, the percentage hemolysis of the control sample in PBS concentration equivalent to $0.3 \mathrm{~g} /$ $100 \mathrm{~mL} \mathrm{NaCl}$ was significantly lower $(p<0.05)$ than that of the sample containing $40 \mathrm{mg} / 100 \mathrm{~mL}$ residual aqueous extract of $A$. occidentale (Fig. 1e).

4.3 Sickle erythrocytes osmotic fragility in the presence of fractionated leaf extracts of $P$. guajava

Figure $2 \mathrm{a}-\mathrm{e}$ showed sickle erythrocytes osmotic fragility in PBS concentrations equivalent to $0.3-0.9 \mathrm{~g} / 100$ $\mathrm{mL} \mathrm{NaCl}$ in the presence of fractionated leaf extracts of $P$. guajava. The percentage hemolysis of the control sample in PBS concentrations equivalent to $0.6 \mathrm{~g} /$ $100 \mathrm{~mL}$ and $0.9 \mathrm{~g} / 100 \mathrm{~mL} \mathrm{NaCl}$ showed no significant difference $(p>0.05)$ from the samples containing $40 \mathrm{mg} / 100 \mathrm{~mL}$ and $80 \mathrm{mg} / 100 \mathrm{~mL}$ petroleum ether extracts of $P$. guajava. Conversely, the percentage hemolysis in the presence of $60 \mathrm{mg} / 100 \mathrm{~mL}$ petroleum ether extract of $P$. guajava in $\mathrm{PBS}$ concentrations equivalent to $0.6 \mathrm{~g} / 100 \mathrm{~mL}$ and $0.9 \mathrm{~g} /$ $100 \mathrm{~mL} \mathrm{NaCl}$ were significantly higher $(p<0.05)$ than that of the control sample (Fig. 2a).

Figure $2 \mathrm{~b}$ showed that the percentage hemolysis of sickle erythrocytes in the presence of $40 \mathrm{mg} / 100 \mathrm{~mL}$ $n$-hexane extract of $P$. guajava in PBS concentrations equivalent to $0.6 \mathrm{~g} / 100 \mathrm{~mL}$ and $0.9 \mathrm{~g} / 100 \mathrm{~mL} \mathrm{NaCl}$ were significantly higher $(p<0.05)$ than that of the control sample as well as the samples containing 60 $\mathrm{mg} / 100 \mathrm{~mL}$ and $80 \mathrm{mg} / 100 \mathrm{~mL} n$-hexane extracts of $P$. guajava. The percentage hemolysis of the sample containing $80 \mathrm{mg} / 100 \mathrm{~mL} n$-hexane extract of $P$. guajava in $\mathrm{PBS}$ concentration equivalent to $0.3 \mathrm{~g} /$ $100 \mathrm{~mL} \mathrm{NaCl}$ was significantly lower $(p<0.05)$ than that of the control sample as well as the test samples containing $40 \mathrm{mg} / 100 \mathrm{~mL}$ and $60 \mathrm{mg} / 100 \mathrm{~mL}$ $n$-hexane extracts of P. guajava (Fig. $2 \mathrm{~b}$ ).

The percentage hemolysis, in PBS concentration equivalent to $0.3 \mathrm{~g} / 100 \mathrm{~mL} \mathrm{NaCl}$, in the presence of $40 \mathrm{mg} / 100 \mathrm{~mL}$ and $80 \mathrm{mg} / 100 \mathrm{~mL}$ chloroform extracts of $P$. guajava as well as the control sample showed no significant difference $(p>0.05)$ but was significantly higher $(p<0.05)$ than that of the sample containing $60 \mathrm{mg} / 100 \mathrm{~mL}$ chloroform extract of P. guajava. Additionally, the percentage hemolysis of the control sample was significantly lower $(p<0.05)$ than the test samples (Fig. 2c).

Figure $2 \mathrm{~d}$ showed that the percentage hemolysis of the control sample in PBS concentrations equivalent to $0.3-0.9 \mathrm{~g} / 100 \mathrm{~mL} \mathrm{NaCl}$ were significantly lower $(p<0.05)$ than those of the samples containing $40 \mathrm{mg} / 100 \mathrm{~mL}, 60 \mathrm{mg} / 100 \mathrm{~mL}$, and 80 $\mathrm{mg} / 100 \mathrm{~mL}$ ethylacetate extracts of $P$. guajava. Conversely, percentage hemolysis in PBS concentrations equivalent to $0.3-0.9 \mathrm{~g} / 100 \mathrm{~mL} \mathrm{NaCl}$ in the presence of $40 \mathrm{mg} / 100 \mathrm{~mL}$ and $80 \mathrm{mg} / 100 \mathrm{~mL}$ ethylacetate extracts of $P$. guajava showed no significant difference $(p>0.05)$ (Fig. 2d).

The percentage hemolysis in PBS concentration equivalent to $0.9 \mathrm{~g} / 100 \mathrm{~mL} \mathrm{NaCl}$ of the control and test samples showed no significant difference $(p>0.05)$ (Fig. 2e). On the contrary, the percentage hemolysis of the control and test samples showed significant difference $(p<0.05)$ in PBS concentration equivalent to $0.3 \mathrm{~g} / 100 \mathrm{~mL} \mathrm{NaCl}$.

\subsection{Sickle erythrocytes osmotic fragility in the presence of fractionated leaf extracts of $T$. catappa}

Figure 3a-e showed sickle erythrocytes osmotic fragility in varying $\mathrm{NaCl}$ concentrations in the presence of fractionated leaf extracts of T. catappa. The percentage hemolysis of the sample containing $60 \mathrm{mg} / 100 \mathrm{~mL}$ petroleum ether extract of T. catappa in PBS concentration equivalent to $0.9 \mathrm{~g} / 100 \mathrm{~mL} \mathrm{NaCl}$ was not significantly different $(p>$ 0.05) from that of the control sample (Fig. 3a). Furthermore, the percentage hemolysis of the control sample and the sample containing $60 \mathrm{mg} / 100 \mathrm{~mL}$ petroleum ether extract of $T$. catappa was significantly lower $(p<0.05)$ than those of the samples, in PBS concentration equivalent to $0.9 \mathrm{~g} / 100 \mathrm{~mL} \mathrm{NaCl}$, containing $40 \mathrm{mg} / 100 \mathrm{~mL}$ and $80 \mathrm{mg} /$ $100 \mathrm{~mL}$ petroleum ether extracts of T. catappa (Fig. 3a).

Figure $3 \mathrm{~b}$ showed that the percentage hemolysis of the control sample and the sample containing $80 \mathrm{mg} / 100$ $\mathrm{mL} n$-hexane extract of $T$. catappa showed no significant difference $(p>0.05)$. However, the percentage hemolysis of the samples containing $40 \mathrm{mg} / 100 \mathrm{~mL}$ and $60 \mathrm{mg} / 100 \mathrm{~mL} n$-hexane extracts of T. catappa were significantly higher $(p<0.05)$ than those of the control sample and the sample containing $80 \mathrm{mg} / 100 \mathrm{~mL} n$-hexane extract of T. catappa.

Figure 3c showed that increasing order of percentage hemolysis, in PBS concentrations equivalent to 0.3-0.9 $\mathrm{g} / 100 \mathrm{~mL} \mathrm{NaCl}$, in the presence of $40 \mathrm{mg} / 100 \mathrm{~mL}, 60$ $\mathrm{mg} / 100 \mathrm{~mL}$, and $80 \mathrm{mg} / 100 \mathrm{~mL}$ chloroform extracts of $T$. catappa showed no significant difference $(p>0.05)$. Notably, the percentage hemolysis of the control sample in PBS concentrations equivalent to $0.3-0.9 \mathrm{~g} / 100 \mathrm{~mL}$ $\mathrm{NaCl}$ were significantly higher $(p<0.05)$ than those of the test samples. 

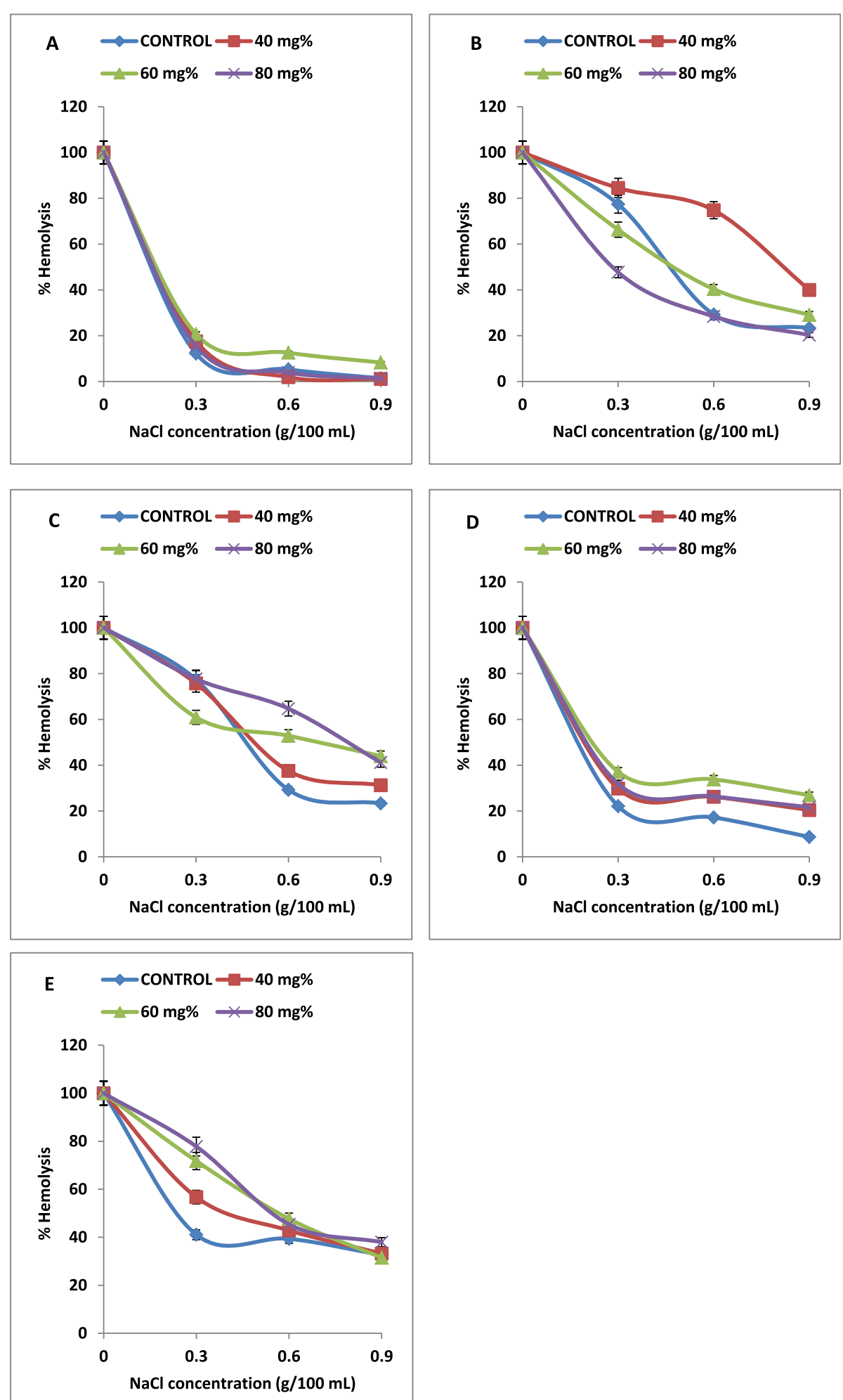

Fig. 2 Erythrocyte osmotic fragility curves: percentage hemolysis of sickle erythrocytes in PBS of varying concentrations equivalent to $0.9-0.3 \mathrm{~g} /$ $100 \mathrm{~mL} \mathrm{NaCl}$ in the presence of fractionated leaf extracts of $P$. quajava. a Petroleum ether. $\mathbf{b} n$-hexane. $\mathbf{c}$ Chloroform. $\mathbf{d}$ Ethylacetate. e Residual aqueous 

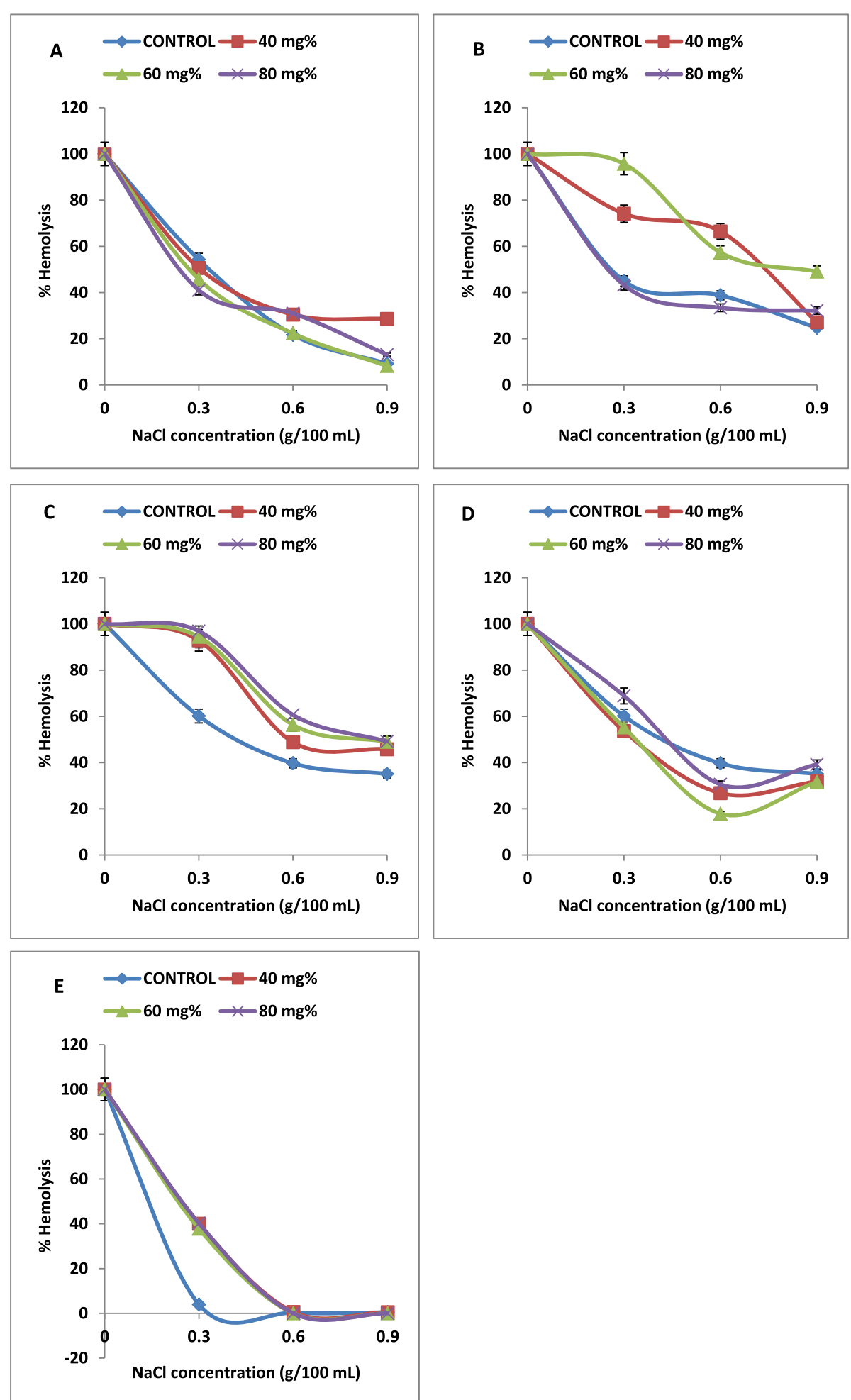

Fig. 3 Erythrocyte osmotic fragility curves: percentage hemolysis of sickle erythrocytes in PBS of varying concentrations equivalent to 0.9-0.3 g/ $100 \mathrm{~mL} \mathrm{NaCl}$ in the presence of fractionated leaf extracts of T. catappa. a Petroleum ether. $\mathbf{b} n$-hexane. $\mathbf{c}$ Chloroform. $\mathbf{d}$ Ethylacetate. e Residual aqueous 
The percentage hemolysis of the control sample, in PBS concentration equivalent to $0.9 \mathrm{~g} / 100 \mathrm{~mL} \mathrm{NaCl}$, was $35.08 \pm 11.64 \%$, whereas those of the test samples ranged between $31.82 \pm 8.32 \%$ and $39.18 \pm 6.94 \%$ (Fig. $3 \mathrm{~d})$. The lowest percentage hemolysis occurred in the sample containing $60 \mathrm{mg} / 100 \mathrm{~mL}$ ethylacetate extract of T. catappa in PBS concentration equivalent to $0.6 \mathrm{~g} / 100$ $\mathrm{mL} \mathrm{NaCl}$.

Figure 3e showed that the sample containing $60 \mathrm{mg} /$ $100 \mathrm{~mL}$ and $80 \mathrm{mg} / 100 \mathrm{~mL}$ residual aqueous extracts of T. catappa in PBS concentration equivalent to $0.9 \mathrm{~g} / 100$ $\mathrm{mL} \mathrm{NaCl}$ exhibited no hemolysis. The percentage hemolysis of the control sample and the sample containing $40 \mathrm{mg} / 100 \mathrm{~mL}$ residual aqueous extract of $T$. catappa were $0.44 \pm 0.18 \%$ and $0.49 \pm 0.09 \%$ respectively. The percentage hemolysis of the control sample, in PBS concentration equivalent to $0.3 \mathrm{~g} / 100 \mathrm{~mL} \mathrm{NaCl}$, was significantly lower $(p<0.05 \%)$ than those of the test samples (Fig. 3e).

\subsection{MCF and percentage stability of sickle erythrocytes}

The MCF and percentage stability of sickle erythrocytes incubated in fractionated leaf extracts of $A$. occidentale, P. guajava, and T. catappa is presented in Table 1.

The results showed that $60 \mathrm{mg} / 100 \mathrm{~mL}$ and $80 \mathrm{mg} /$ $100 \mathrm{~mL}$ petroleum ether extracts of $A$. occidentale stabilized sickle erythrocyte membrane, whereas the sample containing $40 \mathrm{mg} / 100 \mathrm{~mL}$ petroleum ether extract caused the destabilization of sickle erythrocyte membrane. The $80 \mathrm{mg} / 100 \mathrm{~mL}$ petroleum ether extract of $A$. occidentale caused higher erythrocyte membrane stability than that of the sample containing $60 \mathrm{mg} / 100 \mathrm{~mL}$ petroleum ether extract of A. occidentale.

Table 1 Mean corpuscular fragility and percentage stability of sickle erythrocytes in the presence of fractionated leaf extracts of $A$. occidentale, P. guajava, and T. catappa

\begin{tabular}{|c|c|c|c|c|c|c|}
\hline \multirow{2}{*}{$\begin{array}{l}\text { [Extract } \\
\text { fraction] }\end{array}$} & \multicolumn{2}{|c|}{ A. occidentale } & \multicolumn{2}{|l|}{ P. guajava } & \multicolumn{2}{|l|}{ T. catappa } \\
\hline & MCF (g\%) & $\%$ RMS & MCF (g\%) & $\%$ RMS & MCF (g\%) & $\%$ RMS \\
\hline \multicolumn{7}{|c|}{ Petroleum ether } \\
\hline Control & $0.57 \pm 0.24$ & - & $0.17 \pm 0.01$ & - & $0.34 \pm 0.01$ & - \\
\hline 40 mg\% & $0.61 \pm 0.06$ & $7.02^{\mathrm{a}}$ & $0.18 \pm 0.01$ & $5.88^{a}$ & $0.31 \pm 0.03$ & 8.82 \\
\hline 60 mg\% & $0.51 \pm 0.06$ & 10.53 & $0.19 \pm 0.01$ & $11.76^{\mathrm{a}}$ & $0.28 \pm 0.02$ & 17.65 \\
\hline 80 mg\% & $0.48 \pm 0.05$ & 15.79 & $0.18 \pm 0.01$ & $5.88^{a}$ & $0.25 \pm 0.02$ & 9.00 \\
\hline \multicolumn{7}{|l|}{ n-hexane } \\
\hline Control & $0.27 \pm 0.05$ & - & $0.47 \pm 0.04$ & - & $0.28 \pm 0.03$ & - \\
\hline 40 mg\% & $0.26 \pm 0.02$ & 3.70 & $0.81 \pm 0.02$ & $72.34^{\mathrm{a}}$ & $0.73 \pm 0.04$ & $160.71^{\mathrm{a}}$ \\
\hline 60 mg\% & $0.43 \pm 0.06$ & $59.26^{\mathrm{a}}$ & $0.52 \pm 0.09$ & $10.64^{\mathrm{a}}$ & $0.86 \pm 0.01$ & $207.14^{\mathrm{a}}$ \\
\hline 80 mg\% & $0.32 \pm 0.06$ & $18.52^{a}$ & $0.30 \pm 0.06$ & 36.17 & $0.34 \pm 0.15$ & $21.43^{\mathrm{a}}$ \\
\hline \multicolumn{7}{|c|}{ Chloroform } \\
\hline Control & $0.17 \pm 0.01$ & - & $0.47 \pm 0.04$ & - & $0.47 \pm 0.06$ & - \\
\hline 40 mg\% & $0.18 \pm 0.01$ & $5.88^{\mathrm{a}}$ & $0.51 \pm 0.02$ & $8.51^{\mathrm{a}}$ & $0.57 \pm 0.02$ & $21.28^{a}$ \\
\hline 60 mg\% & $0.18 \pm 0.01$ & $5.88^{\mathrm{a}}$ & $0.66 \pm 0.08$ & $40.43^{a}$ & $0.60 \pm 0.02$ & $27.66^{a}$ \\
\hline 80 mg\% & $0.19 \pm 0.01$ & $11.76^{a}$ & $0.78 \pm 0.02$ & $65.96^{\mathrm{a}}$ & $0.62 \pm 0.01$ & $31.91^{a}$ \\
\hline \multicolumn{7}{|c|}{ Ethylacetate } \\
\hline Control & $0.27 \pm 0.05$ & - & $0.19 \pm 0.02$ & - & $0.47 \pm 0.05$ & - \\
\hline 40 mg\% & $0.25 \pm 0.03$ & 7.41 & $0.21 \pm 0.01$ & $10.53^{a}$ & $0.34 \pm 0.02$ & 27.66 \\
\hline 60 mg\% & $0.23 \pm 0.01$ & 14.81 & $0.24 \pm 0.01$ & $26.32^{a}$ & $0.34 \pm 0.01$ & 27.66 \\
\hline 80 mg\% & $0.21 \pm 0.01$ & 22.22 & $0.22 \pm 0.04$ & $15.79^{\mathrm{a}}$ & $0.43 \pm 0.05$ & 8.51 \\
\hline \multicolumn{7}{|c|}{ Residual aqueous } \\
\hline Control & $0.26 \pm 0.02$ & - & $0.26 \pm 0.02$ & - & $0.16 \pm 0.00$ & - \\
\hline 40 mg\% & $0.29 \pm 0.02$ & $11.54^{\mathrm{a}}$ & $0.45 \pm 0.07$ & $73.08^{\mathrm{a}}$ & $0.25 \pm 0.02$ & $56.25^{\mathrm{a}}$ \\
\hline 60 mg\% & $0.23 \pm 0.03$ & 11.54 & $0.58 \pm 0.09$ & $123.08^{\mathrm{a}}$ & $0.25 \pm 0.05$ & $56.25^{a}$ \\
\hline 80 mg\% & $0.22 \pm 0.01$ & 15.38 & $0.52 \pm 0.03$ & $100.00^{\mathrm{a}}$ & $0.26 \pm 0.06$ & $62.50^{\mathrm{a}}$ \\
\hline
\end{tabular}

MCF values are means of 3 determinations \pm S.D

$\% R M S$ relative membrane stability (\%), $g \% \mathrm{~g} / 100 \mathrm{~mL}, \mathrm{mg} \% \mathrm{mg} / 100 \mathrm{~mL}$

${ }^{\mathrm{a}}$ Percentage of membrane destabilization 
The sample containing $40 \mathrm{mg} / 100 \mathrm{~mL} n$-hexane extract of $A$. occidentale stabilized sickle erythrocyte membrane by $3.70 \%$ (Table 1). Further increase in the concentration of $n$ hexane extract of $A$. occidentale caused the destabilization of sickle erythrocyte membrane. The $60 \mathrm{mg} / 100 \mathrm{~mL} n$-hexane extract of $A$. occidentale exhibited greater capacity to destabilize sickle erythrocyte membrane (Table 1).

Table 1 showed that $40 \mathrm{mg} / 100 \mathrm{~mL}$ and $60 \mathrm{mg} / 100$ $\mathrm{mL}$ chloroform extracts of $A$. occidentale exhibited an equal capacity to destabilize sickle erythrocyte membrane. Further increase in the extract concentration exacerbated the destabilizing effect of chloroform extract of $A$. occidentale on the sickle erythrocyte membrane.

The samples containing $40 \mathrm{mg} / 100 \mathrm{~mL}, 60 \mathrm{mg} / 100 \mathrm{~mL}$, and $80 \mathrm{mg} / 100 \mathrm{~mL}$ ethylacetate extracts of $A$. occidentale stabilized sickle erythrocyte membrane in a concentrationdependent manner (Table 1). The capacity of ethylacetate extract to stabilize the sickle erythrocyte membrane was within the range of (7.41-22.22)\% (Table 1).

The $40 \mathrm{mg} / 100 \mathrm{~mL}$ residual aqueous extract of $A$. occidentale caused destabilization of the sickle erythrocyte membrane by $11.54 \%$, whereas $60 \mathrm{mg} / 100 \mathrm{~mL}$ residual aqueous extract of $A$. occidentale stabilized sickle erythrocyte membrane by the same magnitude (Table 1). The capacity of the sickle erythrocyte membrane to withstand osmotic stress was further enhanced in the presence of 80 $\mathrm{mg} / 100 \mathrm{~mL}$ residual aqueous extract of $A$. occidentale (Table 1).

Table 1 showed that $40 \mathrm{mg} / 100 \mathrm{~mL}, 60 \mathrm{mg} / 100 \mathrm{~mL}$, and $80 \mathrm{mg} / 100 \mathrm{~mL}$ petroleum ether extracts of $P$. guajava caused destabilization of the sickle erythrocyte membrane. A cursory look at Table 1 showed that $40 \mathrm{mg} / 100 \mathrm{~mL}$ and $80 \mathrm{mg} / 100$ $\mathrm{mL}$ petroleum ether extracts of $P$. guajava exhibited equal capacity to destabilize sickle erythrocyte membrane.

Table 1 showed that $40 \mathrm{mg} / 100 \mathrm{~mL} n$-hexane extract of $P$. guajava exhibited greater capacity to destabilize sickle erythrocyte membrane than $60 \mathrm{mg} / 100 \mathrm{~mL} n$-hexane extract of $P$. guajava. Further increase in the concentration of $n$-hexane extract of $P$. guajava destabilized sickle erythrocyte membrane by $36.17 \%$ (Table 1 ).

The destabilizing effect of $40 \mathrm{mg} / 100 \mathrm{~mL}, 60 \mathrm{mg} / 100$ $\mathrm{mL}$, and $80 \mathrm{mg} / 100 \mathrm{~mL}$ chloroform extracts of P. guajava on sickle erythrocyte membrane was in a concentrationdependent manner (Table 1). The capacity of chloroform extract of P. guajava to destabilize sickle erythrocyte membrane was within the range of (8.51-65.96)\% (Table 1). Likewise, destabilizing effect of ethylacetate extract of $P$. guajava on sickle erythrocyte membrane was within the range of (15.79-26.32)\% (Table 1). Furthermore, $40 \mathrm{mg} /$ $100 \mathrm{~mL}, 60 \mathrm{mg} / 100 \mathrm{~mL}$, and $80 \mathrm{mg} / 100 \mathrm{~mL}$ residual aqueous extracts of $P$. guajava destabilized sickle erythrocyte membrane within the range of (73.08-123.08)\%.

Table 1 showed that $40 \mathrm{mg} / 100 \mathrm{~mL}, 60 \mathrm{mg} / 100 \mathrm{~mL}$, and $80 \mathrm{mg} / 100 \mathrm{~mL}$ petroleum ether extracts of $T$. catappa stabilized sickle erythrocyte membrane in a concentration-dependent manner. The maximum stabilizing capacity of sickle erythrocyte membrane by petroleum ether extract of T. catappa was $26.47 \%$ (Table 1 ).

The $60 \mathrm{mg} / 100 \mathrm{~mL} n$-hexane extract of $T$. catappa caused the greatest destabilizing effect on sickle erythrocyte membrane compared with the fractionated leaf extracts of A. occidentale, P. guajava, and T. catappa (Table 1). The destabilizing effect of $n$-hexane extract of $T$. catappa on sickle erythrocyte membrane was within the range of (21.43-207.14)\% (Table 1). In the same manner, $40 \mathrm{mg} / 100$ $\mathrm{mL}, 60 \mathrm{mg} / 100 \mathrm{~mL}$, and $80 \mathrm{mg} / 100 \mathrm{~mL}$ chloroform extracts of T. catappa caused destabilization of sickle erythrocyte membrane (Table 1). Table 1 showed that $40 \mathrm{mg} / 100$ $\mathrm{mL}$ and $60 \mathrm{mg} / 100 \mathrm{~mL}$ ethylacetate extracts of T. catappa exhibited equal capacity to stabilize sickle erythrocyte membrane. However, further increase in the concentration of ethylacetate extract of $T$. catappa reduced the capacity of the extract to stabilize sickle erythrocyte membrane (Table 1).

The samples containing $40 \mathrm{mg} / 100 \mathrm{~mL}$ and $60 \mathrm{mg} / 100$ $\mathrm{mL}$ residual aqueous extracts of $T$. catappa caused equal level of destabilization of sickle erythrocyte membrane (Table 1). The destabilizing effect of residual aqueous extract of T. catappa on sickle erythrocyte membrane increased with corresponding increase in the concentration of the extract.

\subsection{Spectrometry}

\subsubsection{GC-MS of fractionated leaf extracts of A. occidentale,}

\section{$P$. guajava, and T. catappa}

The fractionated leaf extracts of $A$. occidentale, $P$. guajava, and $T$. catappa that stabilized sickle erythrocyte membrane against osmotic stress, summarized from Table 1, were as follows: $A$. occidentale (petroleum ether and ethylacetate extracts), $P$. guajava ( $n$-hexane extract), and $T$. catappa (petroleum ether and ethylacetate extracts).

Table 2(A-E) summarized the combinations of phytocomponents present in petroleum ether extract of $A$. occidentale, ethylacetate extract of $A$. occidentale, residual aqueous extract of $A$. occidentale, $n$-hexane extract of $P$. guajava, petroleum ether extract of T. catappa, and ethylacetate extract of T. catappa. Aliphatic compounds in corresponding fractionated leaf extracts of $A$. occidentale, P. guajava, and $T$. catappa are also summarized in Table 2(A-E). The corresponding GC-MS chromatograms of the selected extracts are illustrated in Fig. $4 \mathrm{a}-\mathrm{e}$.

The five major phytocomponents present in A. occidentale were hexadecanoic acid methyl ester, 11-octadecenoic acid methyl ester, pentadecanoic acid 14-methyl-methyl ester, 9,12-octadecadienoic acid (Z, Z)-methyl ester and 9octadecenoic acid, methyl ester, (E)-(Table 2(A)). Table 2(B) showed that pentacosane, in comparative terms, represented the highest abundant phytocomponent 
Table 2 Phytocomponents of (A) petroleum ether extract of A. occidentale, (B) ethylacetate extract of A. occidentale, (C) $n$-hexane extract of P. guajava, (D) petroleum ether extract of T. catappa, (E) ethylacetate extract of $T$. catappa

\begin{tabular}{|c|c|c|c|c|c|}
\hline S/No. & $R_{\mathrm{T}}(\min )$ & Phytocomponents & MF & $\mathrm{MW}(\mathrm{g} / \mathrm{mol})$ & $\%$ PA \\
\hline \multicolumn{6}{|l|}{ (A) } \\
\hline 1. & 5.262 & o-Xylene & $\mathrm{C}_{6} \mathrm{H}_{4}\left(\mathrm{CH}_{3}\right)_{2}$ & 106.16 & 2.30 \\
\hline 2. & 6.811 & Benzene, 1-ethyl-4-methyl- & $\mathrm{C}_{9} \mathrm{H}_{12}$ & 120.1916 & 2.13 \\
\hline 3. & 7.652 & Benzene, 1, 2, 4-trimethyl- & $\mathrm{C}_{9} \mathrm{H}_{12}$ & 120.1916 & 2.33 \\
\hline 4. & 19.205 & Methyl tetradecanoate ${ }^{a}$ & $\mathrm{C}_{15} \mathrm{H}_{30} \mathrm{O}_{2}$ & 242.3975 & 1.53 \\
\hline 5. & 23.437 & Hexadecanoic acid, methyl ester ${ }^{a}$ & $\mathrm{C}_{17} \mathrm{H}_{34} \mathrm{O}_{2}$ & 270.4507 & 49.59 \\
\hline 6. & 23.921 & Pentadecanoic acid, 14-methyl-, methyl ester ${ }^{a}$ & $\mathrm{C}_{17} \mathrm{H}_{34} \mathrm{O}_{2}$ & 270.50 & 10.34 \\
\hline 7. & 27.129 & 9, 12-Octadecadienoic acid (Z, Z)-, methyl ester ${ }^{\mathrm{a}}$ & $\mathrm{C}_{19} \mathrm{H}_{34} \mathrm{O}_{2}$ & 294.4721 & 8.49 \\
\hline 8. & 27.399 & 11-Octadecenoic acid, methyl ester ${ }^{a}$ & $\mathrm{C}_{19} \mathrm{H}_{36} \mathrm{O}_{2}$ & 296.4879 & 14.14 \\
\hline 9. & 27.661 & 9-Octadecenoic acid, methyl ester, $(\mathrm{E})^{-{ }^{a}}$ & $\mathrm{C}_{19} \mathrm{H}_{36} \mathrm{O}_{2}$ & 296.49 & 6.52 \\
\hline 10. & 28.042 & Methyl stearate ${ }^{a}$ & $\mathrm{C}_{19} \mathrm{H}_{38} \mathrm{O}_{2}$ & 298.5 & 2.62 \\
\hline \multicolumn{6}{|l|}{ (B) } \\
\hline 1. & 5.262 & Benzene, 1, 3-dimethyl- & $\mathrm{C}_{8} \mathrm{H}_{10}$ & 106.1650 & 3.97 \\
\hline 2. & 6.826 & 2, 4-Nonadiyne & $\mathrm{C}_{9} \mathrm{H}_{12}$ & 120.19 & 1.33 \\
\hline 3. & 7.684 & Benzene, (1-methylethyl)- & $\mathrm{C}_{9} \mathrm{H}_{12}$ & 120.1916 & 1.31 \\
\hline 4. & 18.562 & Hexacosane $^{a}$ & $\mathrm{C}_{26} \mathrm{H}_{54}$ & 366.718 & 2.27 \\
\hline 5. & 18.617 & Methoxyacetic acid, 3-pentadecyl ester ${ }^{a}$ & $\mathrm{C}_{18} \mathrm{H}_{36} \mathrm{O}_{3}$ & 300.5 & 1.71 \\
\hline 6. & 19.618 & 1-Hexacosanol ${ }^{a}$ & $\mathrm{C}_{26} \mathrm{H}_{54} \mathrm{O}$ & 382.7 & 2.38 \\
\hline 7. & 20.039 & Tetracosane $^{a}$ & $\mathrm{C}_{24} \mathrm{H}_{50}$ & 338.7 & 4.66 \\
\hline 8. & 22.817 & 2-Hexyl-1-octanol ${ }^{a}$ & $\mathrm{C}_{14} \mathrm{H}_{30} \mathrm{O}$ & 214.39 & $<0.01$ \\
\hline 9. & 24.001 & Diisooctyl phthalate ${ }^{a}$ & $\mathrm{C}_{24} \mathrm{H}_{38} \mathrm{O}_{4}$ & 390.6 & $<0.01$ \\
\hline 10. & 24.478 & Bicyclo [4.1.0] heptane-3-cyclopropyl-7-hydroxymethyl [cis] & $\mathrm{C}_{11} \mathrm{H}_{18} \mathrm{O}$ & 166.26002 & $<0.0$ \\
\hline 11. & 24.636 & Tricosane $^{a}$ & $\mathrm{C}_{23} \mathrm{H}_{48}$ & 324.6 & 10.55 \\
\hline 12. & 24.747 & Dibutyl phthalate $^{a}$ & $\mathrm{C}_{16} \mathrm{H}_{22} \mathrm{O}_{4}$ & 278.34 & 29.34 \\
\hline 13. & 27.605 & Undec-10-ynoic acid, undecyl ester ${ }^{\mathrm{a}}$ & $\mathrm{C}_{22} \mathrm{H}_{40} \mathrm{O}_{2}$ & 336.5518 & 1.53 \\
\hline 14. & 27.629 & 3-Cyclopentylpropanoic acid, but-3-yn-2yl ester ${ }^{a}$ & $\mathrm{C}_{12} \mathrm{H}_{18} \mathrm{O}_{2}$ & 194.2701 & $<0.01$ \\
\hline 15. & 28.360 & 4-Nonanol 2, 6, 8 trimethyl- $^{a}$ & $\mathrm{C}_{12} \mathrm{H}_{26} \mathrm{O}$ & 186.3342 & $<0.01$ \\
\hline 16. & 29.717 & Pentacosane $^{a}$ & $\mathrm{C}_{25} \mathrm{H}_{52}$ & 352.7 & 40.95 \\
\hline \multicolumn{6}{|l|}{ (C) } \\
\hline 1. & 25.001 & D-Erythro-sphinganine ${ }^{a}$ & $\mathrm{C}_{18} \mathrm{H}_{39} \mathrm{NO}_{2}$ & 525 & $<0.01$ \\
\hline \multicolumn{6}{|l|}{ (D) } \\
\hline 1. & 5.262 & o-Xylene & $\mathrm{C}_{8} \mathrm{H}_{10}$ & 106.16 & 10.25 \\
\hline 2. & 5.310 & Nonane & $\mathrm{C}_{9} \mathrm{H}_{20}$ & 128.25 & 4.15 \\
\hline 3. & 5.477 & Cyclohexane, 1-ethyl-2-methyl- & $\mathrm{C}_{9} \mathrm{H}_{18}$ & 126.2392 & 1.29 \\
\hline 4. & 5.540 & Trans-1, 3-diethylcyclopentane & $\mathrm{C}_{9} \mathrm{H}_{18}$ & 126.24 & 0.43 \\
\hline 5. & 5.747 & Cyclononene & $\mathrm{C}_{9} \mathrm{H}_{16}$ & 124.22 & 0.87 \\
\hline 6. & 5.913 & Benzene, (1-methylethyl)- & $\mathrm{C}_{9} \mathrm{H}_{12}$ & 120.1916 & 1.37 \\
\hline 7. & 5.985 & Cyclohexane, propyl- & $\mathrm{C}_{9} \mathrm{H}_{18}$ & 126.2392 & 0.61 \\
\hline 8. & 6.048 & Octane, 2, 6-dimethyl- & $\mathrm{C}_{10} \mathrm{H}_{22}$ & 142.2817 & 1.01 \\
\hline 9. & 6.176 & 1, 15-Pentadecanediol ${ }^{a}$ & $\mathrm{C}_{15} \mathrm{H}_{32} \mathrm{O}_{2}$ & 244.4134 & 0.39 \\
\hline 10. & 6.596 & Benzene, propyl- & $\mathrm{C}_{9} \mathrm{H}_{12}$ & 120.1916 & 2.30 \\
\hline 11. & 6.715 & Nonane, 4-methyl- & $\mathrm{C}_{10} \mathrm{H}_{22}$ & 142.2817 & 0.41 \\
\hline 12. & 6.819 & Benzene, 1-ethyl-3-methyl- & $\mathrm{C}_{9} \mathrm{H}_{12}$ & 120.1916 & 11.17 \\
\hline 13. & 6.946 & Nonane, 3-methyl- & $\mathrm{C}_{10} \mathrm{H}_{22}$ & 142.2817 & 0.39 \\
\hline 14. & 7.017 & Benzene, 1, 2, 3-trimethyl- & $\mathrm{C}_{9} \mathrm{H}_{12}$ & 120.1916 & 4.44 \\
\hline
\end{tabular}


Table 2 Phytocomponents of (A) petroleum ether extract of A. occidentale, (B) ethylacetate extract of A. occidentale, (C) n-hexane extract of P. guajava, (D) petroleum ether extract of T. catappa, (E) ethylacetate extract of T. catappa (Continued)

\begin{tabular}{|c|c|c|c|c|c|}
\hline S/No. & $R_{\mathrm{T}}(\mathrm{min})$ & Phytocomponents & MF & MW (g/mol) & $\% \mathrm{PA}$ \\
\hline 15. & 7.263 & Benzene, 1-ethyl-2-methyl- & $\mathrm{C}_{9} \mathrm{H}_{12}$ & 120.1916 & 2.59 \\
\hline 16. & 7.652 & Benzene, 1, 2, 3-trimethyl- & $\mathrm{C}_{9} \mathrm{H}_{12}$ & 120.1916 & 12.76 \\
\hline 17. & 8.407 & Spiro [bicycle [2.2.1] hept-5-ene-2, 1'-cyclopropane] ${ }^{\mathrm{a}}$ & $\mathrm{C}_{9} \mathrm{H}_{12}$ & 120.19 & 7.66 \\
\hline 18. & 8.732 & Indane & $\mathrm{C}_{9} \mathrm{H}_{10}$ & 118.18 & 2.77 \\
\hline 19. & 9.010 & Indene & $\mathrm{C}_{9} \mathrm{H}_{8}$ & 116.16 & 0.60 \\
\hline 20. & 9.089 & Benzene, 1, 4-diethyl- & $\mathrm{C}_{10} \mathrm{H}_{14}$ & 134.2182 & 0.97 \\
\hline 21. & 9.153 & Benzene, 1-methyl-3-propyl- & $\mathrm{C}_{10} \mathrm{H}_{14}$ & 134.2182 & 1.16 \\
\hline 22. & 9.264 & p-Mentha-1, 5, 8-triene & $\mathrm{C}_{10} \mathrm{H}_{14}$ & 134.2182 & 1.16 \\
\hline 23. & 9.375 & Benzene, 2-ethyl-1, 3-dimethyl- & $\mathrm{C}_{10} \mathrm{H}_{14}$ & 134.2182 & 1.90 \\
\hline 24. & 9.518 & 3a, 4, 5, 6, 7, 7a-Hexahydro-4, 7-methanoindene & $\mathrm{C}_{10} \mathrm{H}_{14}$ & 134.2182 & 1.51 \\
\hline 25. & 9.876 & Benzene, 4-ethyl-1, 2-dimethyl- & $\mathrm{C}_{10} \mathrm{H}_{14}$ & 134.2182 & 1.03 \\
\hline 26. & 9.939 & Benzene, 1-ethyl-2, 4-dimethyl- & $\mathrm{C}_{10} \mathrm{H}_{14}$ & 134.2182 & 1.53 \\
\hline 27. & 10.011 & 1-Penten-3-yne, 2-methyl- & $\mathrm{C}_{6} \mathrm{H}_{8}$ & 80.1277 & 0.84 \\
\hline 28. & 10.114 & Benzene, 2-ethyl-1, 4-dimethyl- & $\mathrm{C}_{10} \mathrm{H}_{14}$ & 134.2182 & 3.65 \\
\hline 29. & 10.122 & Benzene 1-methyl-4-(-2-propenyl-) & $\mathrm{C}_{10} \mathrm{H}_{12}$ & 132.2023 & $<0.01$ \\
\hline 30. & 10.225 & 4, 7-Methano-1H-indene, octahydro- & $\mathrm{C}_{10} \mathrm{H}_{16}$ & 136.2340 & 2.02 \\
\hline 31. & 10.415 & Undecane & $\mathrm{C}_{11} \mathrm{H}_{24}$ & 156.313 & 0.59 \\
\hline 32. & 10.471 & 1-Penten-3-yne, 2-methyl- & $\mathrm{C}_{6} \mathrm{H}_{8}$ & 80.1277 & 0.67 \\
\hline 33. & 10.693 & o-Cymene $e^{a}$ & $\mathrm{C}_{10} \mathrm{H}_{14}$ & 134.2182 & 0.49 \\
\hline 34. & 10.995 & Benzene, 1, 2, 3, 4-tetramethyl- & $\mathrm{C}_{10} \mathrm{H}_{14}$ & 134.2182 & 0.87 \\
\hline 35. & 11.122 & Benzene, 1, 2, 3, 5-tetramethyl- & $\mathrm{C}_{10} \mathrm{H}_{14}$ & 134.2182 & 1.60 \\
\hline 36. & 11.591 & (E)-1-Phenyl-1-butene & $\mathrm{C}_{10} \mathrm{H}_{12}$ & 132.2023 & 1.35 \\
\hline 37. & 11.876 & 2,4-Dimethylstyrene & $\mathrm{C}_{10} \mathrm{H}_{12}$ & 132.2023 & 2.73 \\
\hline 38. & 12.043 & Benzene, 1-butynyl- & $\mathrm{C}_{10} \mathrm{H}_{10}$ & 130.1864 & 0.73 \\
\hline 39. & 12.170 & 1-Hexen-3-yne & $\mathrm{C}_{6} \mathrm{H}_{8}$ & 80.13 & 0.67 \\
\hline 40. & 12.480 & Benzene, 1-methyl-4-(1-methylpropyl)- ${ }^{a}$ & $\mathrm{C}_{11} \mathrm{H}_{16}$ & 148.2447 & 0.41 \\
\hline 41. & 12.797 & Naphthalene & $\mathrm{C}_{10} \mathrm{H}_{8}$ & 128.17 & 2.54 \\
\hline 42. & 13.036 & Benzene, (1-methyl-1-butenyl)- & $\mathrm{C}_{11} \mathrm{H}_{14}$ & 146.2289 & 1.62 \\
\hline 43. & 13.838 & Benzene, (1-ethyl-1-propenyl)- & $\mathrm{C}_{11} \mathrm{H}_{14}$ & 146.2289 & 0.56 \\
\hline 44. & 14.179 & Benzene, (3-methyl-2-butenyl)- & $\mathrm{C}_{11} \mathrm{H}_{14}$ & 146.2289 & 0.48 \\
\hline 45. & 14.449 & Benzene, 2-ethenyl-1, 3, 5-trimethyl & $\mathrm{C}_{11} \mathrm{H}_{14}$ & 146.2289 & 0.63 \\
\hline 46. & 15.148 & Benzocycloheptatriene & $\mathrm{C}_{11} \mathrm{H}_{10}$ & 142.1971 & 0.99 \\
\hline 47. & 15.457 & Naphthalene, 2-methyl- & $\mathrm{C}_{11} \mathrm{H}_{10}$ & 142.1971 & 0.54 \\
\hline 48. & 21.087 & Isoxazole, 4, 5-dimethyl- ${ }^{a}$ & $\mathrm{C}_{5} \mathrm{H}_{7} \mathrm{NO}$ & 97.12 & 0.47 \\
\hline 49. & 23.993 & Hexadecanoic acid ${ }^{a}$ & $\mathrm{C}_{16} \mathrm{H}_{32} \mathrm{O}_{2}$ & 256.4241 & $<0.01$ \\
\hline 50. & 27.606 & 10-Octadecenoic acid, methyl ester ${ }^{a}$ & $\mathrm{C}_{19} \mathrm{H}_{36} \mathrm{O}_{2}$ & 296.5 & 0.82 \\
\hline 51. & 28.336 & Methyl stearate ${ }^{a}$ & $\mathrm{C}_{19} \mathrm{H}_{38} \mathrm{O}_{2}$ & 298.5 & $<0.01$ \\
\hline \multicolumn{6}{|l|}{ (E) } \\
\hline 1. & 24.009 & Hexadecanoic acid, methyl ester ${ }^{a}$ & $\mathrm{C}_{17} \mathrm{H}_{34} \mathrm{O}_{2}$ & 270.4507 & 20.03 \\
\hline 2. & 27.494 & 9, 11-Octadecadienoic acid, methyl ester, $\left(E, E^{-}\right)^{a}$ & $\mathrm{C}_{19} \mathrm{H}_{34} \mathrm{O}_{2}$ & 294.5 & 18.26 \\
\hline 3. & 27.701 & Trans-13-octadecenoic acid, methyl ester ${ }^{\mathrm{a}}$ & $\mathrm{C}_{19} \mathrm{H}_{36} \mathrm{O}_{2}$ & 296.4879 & 49.49 \\
\hline 4. & 28.368 & Methyl stearate ${ }^{a}$ & $\mathrm{C}_{19} \mathrm{H}_{38} \mathrm{O}_{2}$ & 298.5 & 12.22 \\
\hline
\end{tabular}

$R_{T}$ retention time, $M F$ molecular formula, $M W$ molecular weight, $P A$ peak area, \%PA $<0.01$ trace amount [56] aplant metabolite 

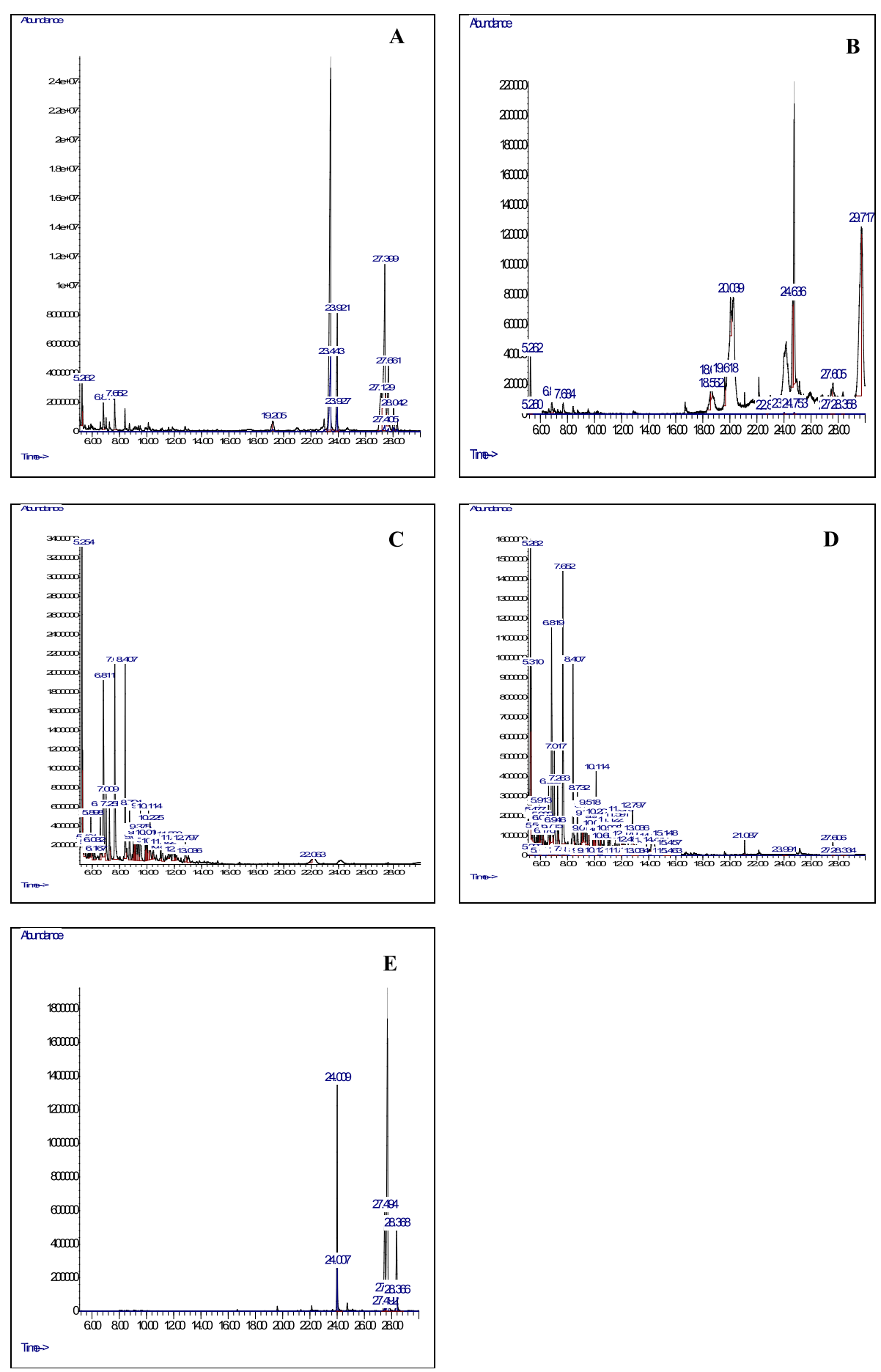

Fig. 4 GC-MS chromatograms: a Petroleum ether extract of A. occidentale. $\mathbf{b}$ Ethylacetate extract of $A$. occidentale. $\mathbf{c} n$-hexane extract of $P$. guajava. d Petroleum ether extract of T. catappa. e Ethylacetate extract of T. catappa

present in ethylacetate extract of $A$. occidentale. Other notable phytocomponents present in ethylacetate extract of $A$. occidentale were dibutyl phthalate, hexacosane, 1hexacosanol, tetracosane, 2-hexyl-1-octanol, diisooctyl phthalate, tricosane, undec-10-ynoic acid undecyl ester, and 3-cyclopentylpropanoic acid but-3-yn-2yl ester.

Table 2(C) showed the presence of D-erythro-sphinganine in $n$-hexane extract of P. guajava. Table 2(D) showed the 
presence of 51 phytocomponents in petroleum ether extract of T. catappa. Notable phytocomponents of petroleum ether extract of T. catappa were 1,15-pentadecanediol, 4,7-methano- $1 \mathrm{H}$-indene, octahydro-, hexadecanoic acid, 10-octadecenoic acid methyl ester, and methyl stearate. Ethylacetate extract of $T$. catappa contained comparative high quantities of hexadecanoic acid methyl ester, 9, 11-octadecadienoic acid, methyl ester, (E, E)-, trans-13octadecenoic acid methyl ester, and methyl stearate.

4.6.2 FT-IR of fractionated leaf extracts of $A$. occidentale, $P$. guajava, and T. catappa

The FT-IR spectra of the selected leaf extracts, namely ethylacetate and petroleum ether extracts of A. occidentale, $n$-hexane extract of $P$. guajava, and petroleum ether and ethylacetate extracts of $T$. catappa are illustrated in Fig. 5a-e and summarized in Table 3(A-E).

Petroleum ether extract of $A$. occidentale exhibited characteristic strong and medium bands within the range of (2955.8-2855.1) $\mathrm{cm}^{-1}$ and (905.7-693.3) $\mathrm{cm}^{-1}$ (Fig. 5a), which were indicative of the presence of aliphatic compounds and aromatic mono- and di-substituted aromatic compounds (Table $3(\mathrm{~A})$ ). Weak band at $1748.1 \mathrm{~cm}^{-1}$ was indicative of the presence of ester carbonyl group bearing molecules. Other notable molecular constituents present were aldehyde, phenolics, acyl halides, and alkoxy functional groups containing compounds.

Figure $5 \mathrm{~b}$ showed that ethylacetate extract of $A$. occidentale contained alcohol functional group $(\mathrm{O}-\mathrm{H})$ bearing molecules. Peaks within the range of (2989.1-2907.3) $\mathrm{cm}^{-1}$ were indicative of the presence of saturated aliphatic compounds (Table 3(B)). The presence of aromatic compounds in the extract was typified by peaks around $1446.2 \mathrm{~cm}^{-1}$, $786.5 \mathrm{~cm}^{-1}$, and $733.0 \mathrm{~cm}^{-1}$ (Table 3(B)). A medium band at $1376.9 \mathrm{~cm}^{-1}$ and peaks within the range of (1889.81654.9) $\mathrm{cm}^{-1}$ suggested the presence of acyl group, phenolics, as well as carboxylic acid, esters, and amide functional groups in ethylacetate extract of A. occidentale (Table 3(B)).

The presence of saturated aliphatic and aromatic compounds in $n$-hexane extract of $P$. guajava was typified by multiple weak and strong bands within the range of (2952.8-2858.9) $\mathrm{cm}^{-1}$ and (909.5-83.08) $\mathrm{cm}^{-1}$ (Fig. 5c). The presence of aromatic compounds as exemplified by weak band around $1457.4 \mathrm{~cm}^{-1}$. Furthermore, weak bands within the range of (1990.4-697.0) $\mathrm{cm}^{-1}$ suggested the presence of conjugated alkenes, primary and tertiary amines, di-substituted aromatic compounds, and cis-alkenes (Table $3(\mathrm{C})$ ).

The weak band around 3734.80 denotes $\mathrm{N}-\mathrm{H}$ and $\mathrm{O}-\mathrm{H}$ stretch, which suggested the presence of amide and alcohol functional groups bearing molecules (Fig. 5d). Peaks within the range of (3112.3-2851.4) $\mathrm{cm}^{-1}$ were indicative of the presence of aliphatic compounds in petroleum ether extract of T. catappa (Table 3(D)). Petroleum ether extract of T. catappa contained carbonyl and alkoxy functional groups as indicated by weak bands at $1733.2 \mathrm{~cm}^{-1}$ and $1039.9 \mathrm{~cm}^{-1}$ respectively. Additionally, peaks around (887.1-801.4) $\mathrm{cm}^{-1}$ were indicative of the presence of aromatic compounds (Table 3(D)).

The broad band at $3410.5 \mathrm{~cm}^{-1}$ was characteristic of the presence of alcohol functional group $(\mathrm{O}-\mathrm{H})$ in ethylacetate extract of T. catappa (Fig. 5e). Additionally, the peaks within the range of (2981.9-2907.3) $\mathrm{cm}^{-1}$ and (939.3-849.8) $\mathrm{cm}^{-1}$ suggested the presence of aliphatic compounds. Table 3(E) showed the presence of aromatic compounds as well as nitro-compounds, phenolics, and esters.

\subsubsection{UV-visible of fractionated leaf extracts of $A$. occidentale, P. guajava, and T. catappa}

The selected fractionated leaf extracts of $A$. occidentale, $P$. guajava, and T. catappa gave characteristic UV-visible spectra (Fig. 6a-e). Petroleum ether extract of A. occidentale exhibited multiple $\lambda \max$ around region of $272.00 \mathrm{~nm}$, which suggested the presence of nitro-containing chromophores in the extract (Fig. 6a). The $\lambda$ max of ethylacetate extract of $A$. occidentale was at $205.00 \mathrm{~nm}$ (Fig. 6b). Figure 6c showed multiple peak values of UV-visible spectra of $n$-hexane extract of P. guajava. Petroleum ether extract of T. catappa exhibited multiple distinct peaks within a broad range of $204.00 \mathrm{~nm}$ and $671.00 \mathrm{~nm}$ (Fig. 6d). Ethylacetate extract of T. catappa gave single $\lambda$ max at $363.00 \mathrm{~nm}$ (Fig. 6e).

\section{Discussion}

The capacity of phytocomponents to alter erythrocyte membrane stability is measured in vitro when a given population of erythrocyte is suspended in hypotonic solutions of varying $\mathrm{NaCl}$ concentrations [25, 26, 42]. Previous studies had reported distortions in membrane osmotic stability of human erythrocyte genotypes, in health and disease, and the capacities of plant extracts to reverse those alterations $[26,42,44$, 57-59]. Certain phytocomponents are associated with stabilization of erythrocyte membrane integrity or, on the contrary, cause exacerbated hemolysis in hypotonic solutions [44, 60-62]. For instance, certain classes of the tannins, aminoglycosides, and saponins from verse collections of plant species have been implicated in eliciting erythrocyte membrane destabilization by their chaotropic interaction with biomembrane components [1, 21, 57, 62-64]. The destabilizing effects elicited by phytochemicals are analogous to hemolytic actions of intra-erythrocytic denatured hemoglobin precipitate-Heinz bodies. According to Jarolim et al. [65], Heinz bodies form an attachment with erythrocyte membrane components, which elicits striking membrane damage, evidenced by increased membrane lipid peroxidation and cross-linked membrane proteins. The damaged sickle erythrocyte membrane is characterized by calcium-activated increased permeability of potassium, phospholipids bilayer 

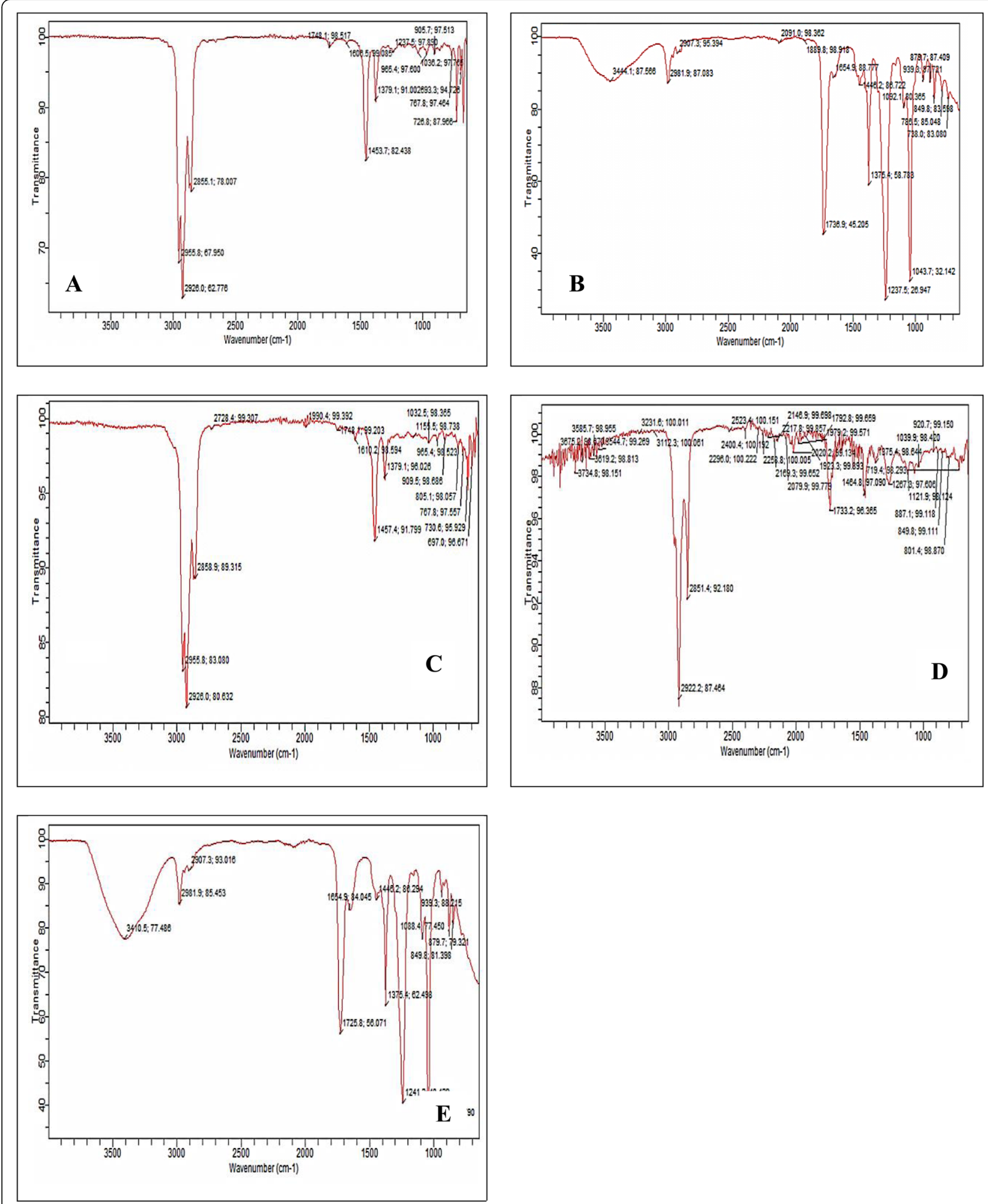

Fig. 5 FT-IR spectra of a Petroleum ether extract of A. occidentale. $\mathbf{b}$ Ethylacetate extract of $A$. occidentale. $\mathbf{c} n$-hexane extract of $P$. guajava. $\mathbf{d}$ Petroleum ether extract of T. catappa. e Ethylacetate extract of T. catappa 
Table 3 FT-IR spectra peak values: (A) petroleum ether extract of A. occidentale, (B) ethylacetate extract of A. occidentale, (C) $n$ hexane extract of $P$. guajava, (D) petroleum ether extract of $T$. catappa, (E) ethylacetate extract of $T$. catappa

\begin{tabular}{|c|c|c|c|c|}
\hline S/No & Peak/band $\left(\mathrm{cm}^{-1}\right)$ & $\% \mathrm{~T}$ & Functional groups/assignment & Origin \\
\hline \multicolumn{5}{|l|}{ (A) } \\
\hline 1. & 2955.8 & 67.950 & Alkanes sp3 C-H stretch & $\mathrm{C}-\mathrm{H}$ \\
\hline 2. & 2926.0 & 62.776 & Alkanes sp3 C-H stretch & $\mathrm{C}-\mathrm{H}$ \\
\hline 3. & 2855.1 & 78.007 & Aldehyde $\mathrm{C}-\mathrm{H}$ stretch & $\mathrm{C}-\mathrm{H}$ \\
\hline 4. & 1748.1 & 98.517 & Ester carbonyl C-O stretch & $\mathrm{C}=\mathrm{O}$ \\
\hline 5. & 1606.5 & 99.085 & Conjugated alkenes C-C & $C=C$ \\
\hline 6. & 1453.7 & 82.438 & Aromatic compounds C-C stretch & $C=C$ \\
\hline 7. & 1379.4 & 91.002 & Acyl C-O; phenol C-O stretch & $\mathrm{C}=\mathrm{O} ; \mathrm{C}-\mathrm{O}$ \\
\hline 8. & 1237.5 & 97.513 & Aromatic ethers, aryl-O stretch & Ar-O-C \\
\hline 9. & 1036.2 & 97.765 & Alkoxy C-O stretch & $\mathrm{X}-\mathrm{O}-\mathrm{C}$ \\
\hline 10. & 905.7 & 97.513 & Mono-substituted alkene sp2 C-H bend & $=\mathrm{C}-\mathrm{H}$ \\
\hline 11. & 767.8 & 97.464 & Di-substituted aromatic sp2 $\mathrm{C}-\mathrm{H}$ bend & $=\mathrm{C}-\mathrm{H}$ \\
\hline 12. & 726.8 & 87.966 & Mono-substituted aromatic sp2 C-H bend & $=\mathrm{C}-\mathrm{H}$ \\
\hline 13. & 693.3 & 94.726 & Di-substituted aromatic sp2 C-H bend & $=\mathrm{C}-\mathrm{H}$ \\
\hline \multicolumn{5}{|l|}{ (B) } \\
\hline 1. & 3444.1 & 87.566 & Dimeric O-H stretch & $\mathrm{O}-\mathrm{H}$ \\
\hline 2. & 2989.1 & 87.083 & Alkanes sp3 C-H stretch & $\mathrm{C}-\mathrm{H}$ \\
\hline 3. & 2907.3 & 95.394 & Alkanes sp3 C-H stretch & $\mathrm{C}-\mathrm{H}$ \\
\hline 4. & 2091.0 & 98.362 & Isothiocyanate (-SCN) stretch & $-\mathrm{SCN}$ \\
\hline 5. & 1889.8 & 98.918 & Carboxylic acids C-O stretch & $\mathrm{C}=\mathrm{O}$ \\
\hline 6. & 1736.9 & 45.205 & Ester C-O stretch & $\mathrm{C}=\mathrm{O}$ \\
\hline 7. & 1654.9 & 88.777 & Amides C-O stretch & $\mathrm{C}=\mathrm{O}$ \\
\hline 8. & 1446.2 & 86.722 & Aromatic C-C stretch & $C=C$ \\
\hline 9. & 1376.9 & 45.205 & Acyl C-O; phenol C-O stretch & $\mathrm{C}=\mathrm{O} ; \mathrm{C}-\mathrm{O}$ \\
\hline 10. & 1237.5 & 26.947 & Skeletal C-C vibration & $C-C$ \\
\hline 11. & 1092.1 & 80.365 & Alkoxy C-O stretch & $\mathrm{X}-\mathrm{O}-\mathrm{C}$ \\
\hline 12. & 1043.7 & 32.142 & Primary amine C-N stretch & $\mathrm{C}-\mathrm{N}$ \\
\hline 13. & 939.3 & 87.721 & Alkenes sp2 C-H bend & $=\mathrm{C}-\mathrm{H}$ \\
\hline 14. & 878.7 & 87.409 & Alkenes sp2 C-H bend & $=\mathrm{C}-\mathrm{H}$ \\
\hline 15. & 849.8 & 83.588 & Tri-substituted alkenes sp2 C-H bend & $\mathrm{C}-\mathrm{H}$ \\
\hline 16. & 786.5 & 85.048 & Di-substituted aromatic sp C-H bend & $\mathrm{C}-\mathrm{H}$ \\
\hline 17. & 733.0 & 83.080 & Mono-substituted aromatic $\mathrm{C}-\mathrm{H}$ bend & $\mathrm{C}-\mathrm{H}$ \\
\hline \multicolumn{5}{|l|}{ (C) } \\
\hline 1. & 2952.8 & 83.080 & Alkanes sp3 C-H stretch & $\mathrm{C}-\mathrm{H}$ \\
\hline 2. & 2926.0 & 60.632 & Alkanes sp3 C-H stretch & $\mathrm{C}-\mathrm{H}$ \\
\hline 3. & 2858.9 & 89.315 & Alkanes sp3 C-H stretch & $\mathrm{C}-\mathrm{H}$ \\
\hline 4. & 2728.4 & 99.307 & Aldehyde $\mathrm{C}-\mathrm{H}$ stretch & $\mathrm{C}-\mathrm{H}$ \\
\hline 5. & 1990.4 & 99.392 & Cyanate C-N stretch & $-\mathrm{C} \equiv \mathrm{N}$ \\
\hline 6. & 1748.1 & 99.203 & Esters C-O stretch & $\mathrm{C}=\mathrm{O}$ \\
\hline 7. & 1610.2 & 98.594 & Conjugated alkenes C-C stretch & $C=C$ \\
\hline 8. & 1457.4 & 91.799 & Aromatic ring stretch & $C=C-C$ \\
\hline 9. & 1379.1 & 96.026 & Alkanes sp3 C-H bend & $\mathrm{C}-\mathrm{H}$ \\
\hline 10. & 1155.5 & 98.738 & Tertiary amine C-N stretch & $\mathrm{C}-\mathrm{N}$ \\
\hline
\end{tabular}


Table 3 FT-IR spectra peak values: (A) petroleum ether extract of A. occidentale, (B) ethylacetate extract of A. occidentale, (C) $n$ hexane extract of $P$. guajava, (D) petroleum ether extract of T. catappa, (E) ethylacetate extract of T. catappa (Continued)

\begin{tabular}{|c|c|c|c|c|}
\hline $\mathrm{S} / \mathrm{No}$ & Peak/band $\left(\mathrm{cm}^{-1}\right)$ & $\% \mathrm{~T}$ & Functional groups/assignment & Origin \\
\hline 11. & 1032.5 & 98.385 & Primary amine C-N stretch & $\mathrm{C}-\mathrm{N}$ \\
\hline 12. & 909.5 & 98.686 & Vinyl $\mathrm{C}-\mathrm{H}$ bend & $\mathrm{C}-\mathrm{H}$ \\
\hline 13. & 805.1 & 98.057 & Di-substituted aromatic $\mathrm{C}-\mathrm{H}$ bend & $\mathrm{C}-\mathrm{H}$ \\
\hline 14. & 767.8 & 97.557 & Di-substituted aromatic $\mathrm{C}-\mathrm{H}$ bend & $\mathrm{C}-\mathrm{H}$ \\
\hline 15. & 730.6 & 95.929 & Cis-alkene sp2 C-H bend & $\mathrm{C}-\mathrm{H}$ \\
\hline 16. & 697.0 & 96.671 & Cis-alkene sp2 C-H bend & $\mathrm{C}-\mathrm{H}$ \\
\hline \multicolumn{5}{|l|}{ (D) } \\
\hline 1. & 3734.8 & 98.151 & Amide and alcohol $\mathrm{N}-\mathrm{H}$ and $\mathrm{O}-\mathrm{H}$ stretch & $\mathrm{N}-\mathrm{H} ; \mathrm{O}-\mathrm{H}$ \\
\hline 2. & 3112.3 & 100.06 & Alkynes sp C-H stretch & $\equiv \mathrm{C}-\mathrm{H}$ \\
\hline 3. & 2922.2 & 87.464 & Alkanes sp3 C-H bend & $\mathrm{C}-\mathrm{H}$ \\
\hline 4. & 2851.4 & 92.180 & Alkanes sp3 C-H bend & $\mathrm{C}-\mathrm{H}$ \\
\hline 5. & 2079.9 & 99.779 & Isothiocyanate (-NCS) stretch & $N \equiv C-S$ \\
\hline 6. & 2020.2 & 99.134 & Isothiocyanate (-NCS) stretch & $N \equiv C-S$ \\
\hline 7. & 1733.2 & 96.365 & Aldehyde C-O stretch & $\mathrm{C}=\mathrm{O}$ \\
\hline 8. & 1464.8 & 97.090 & Aromatics compounds sp2 C-C stretch & $\mathrm{C}=\mathrm{C}$ \\
\hline 9. & 1121.9 & 96.124 & Alkyl substituted alkoxy C-O stretch & $\mathrm{C}-\mathrm{O}-\mathrm{C}$ \\
\hline 10. & 1039.9 & 98.420 & Alkoxy C-O stretch & $\mathrm{X}-\mathrm{O}-\mathrm{C}$ \\
\hline 11. & 920.7 & 99.150 & Alkenes sp2 C-H bend & $\mathrm{C}-\mathrm{H}$ \\
\hline 12. & 887.1 & 99.118 & Di-substituted aromatics sp2 C-H stretch & $\mathrm{C}-\mathrm{H}$ \\
\hline 13. & 849.8 & 99.111 & Di-substituted aromatics sp2 C-H stretch & $\mathrm{C}-\mathrm{H}$ \\
\hline 14. & 801.4 & 98.870 & Di-substituted aromatics sp2 C-H stretch & $\mathrm{C}-\mathrm{H}$ \\
\hline \multicolumn{5}{|l|}{ (E) } \\
\hline 1. & 3410.5 & 77.486 & Alcohols O-H stretch & $\mathrm{O}-\mathrm{H}$ \\
\hline 2. & 2981.9 & 85.453 & Alkanes sp3 C-H stretch & $\mathrm{C}-\mathrm{H}$ \\
\hline 3. & 2907.3 & 93.016 & Alkanes sp3 C-H stretch & $\mathrm{C}-\mathrm{H}$ \\
\hline 4. & 1725.8 & 56.071 & Aldehyde C-O stretch & $\mathrm{C}=\mathrm{O}$ \\
\hline 5. & 1446.2 & 86.294 & Aromatic compounds C-C stretch & $\mathrm{C}=\mathrm{C}$ \\
\hline 6. & 1375.4 & 62.498 & Nitro compounds $\mathrm{NO}_{2}$ stretch & $-\mathrm{N}=\mathrm{O}$ \\
\hline 7. & 1241.2 & 40.429 & Acyl C-O; phenol C-O stretch & $\mathrm{C}-\mathrm{O}$ \\
\hline 8. & 1088.4 & 77.450 & Alkoxy C-O stretch & $\mathrm{X}-\mathrm{O}-\mathrm{C}$ \\
\hline 9. & 1043.7 & 35.790 & Alkoxy C-O stretch & $\mathrm{X}-\mathrm{O}-\mathrm{C}$ \\
\hline 10. & 939.3 & 88.215 & Mono-alkene sp2 C-H bend & $\mathrm{C}-\mathrm{H}$ \\
\hline 11. & 879.7 & 79.321 & Alkene sp2 $\mathrm{C}-\mathrm{H}$ bend & $\mathrm{C}-\mathrm{H}$ \\
\hline 12. & 849.8 & 81.398 & Alkene sp2 $\mathrm{C}-\mathrm{H}$ bend & $\mathrm{C}-\mathrm{H}$ \\
\hline
\end{tabular}

$\% \mathrm{~T}$ percentage transmittance

destabilization, decreased deformability and unusual assemblies, and interactions of membrane proteins as well as unusual oxidation of protein thiols and cytoskeletal dysfunction $[66,67]$. Furthermore, the use of mathematical models had revealed the relationship between sickle hemoglobin $(\mathrm{HbS})$ polymerization and membrane morphology, osmotic properties, viscoelasticity, rheology, and related physicochemical characteristics of sickle erythrocytes as empirically described [67-69]. By implication, phytocomponents that deterred
HbS aggregation and polymerization improved sickle erythrocyte membrane stability $[35,59,70,71]$ within limits of their permeability across the biomembrane system as previously described [72]. In line with the present findings, the presence of isothiocyanates, a notable anti-HbS polymerization phytochemicals [70, 71], in ethylacetate extract of $A$. occidentale obviously contributed, in parts, in stabilizing the sickle erythrocyte membrane against osmotic stress. Additionally, aromatic compounds 

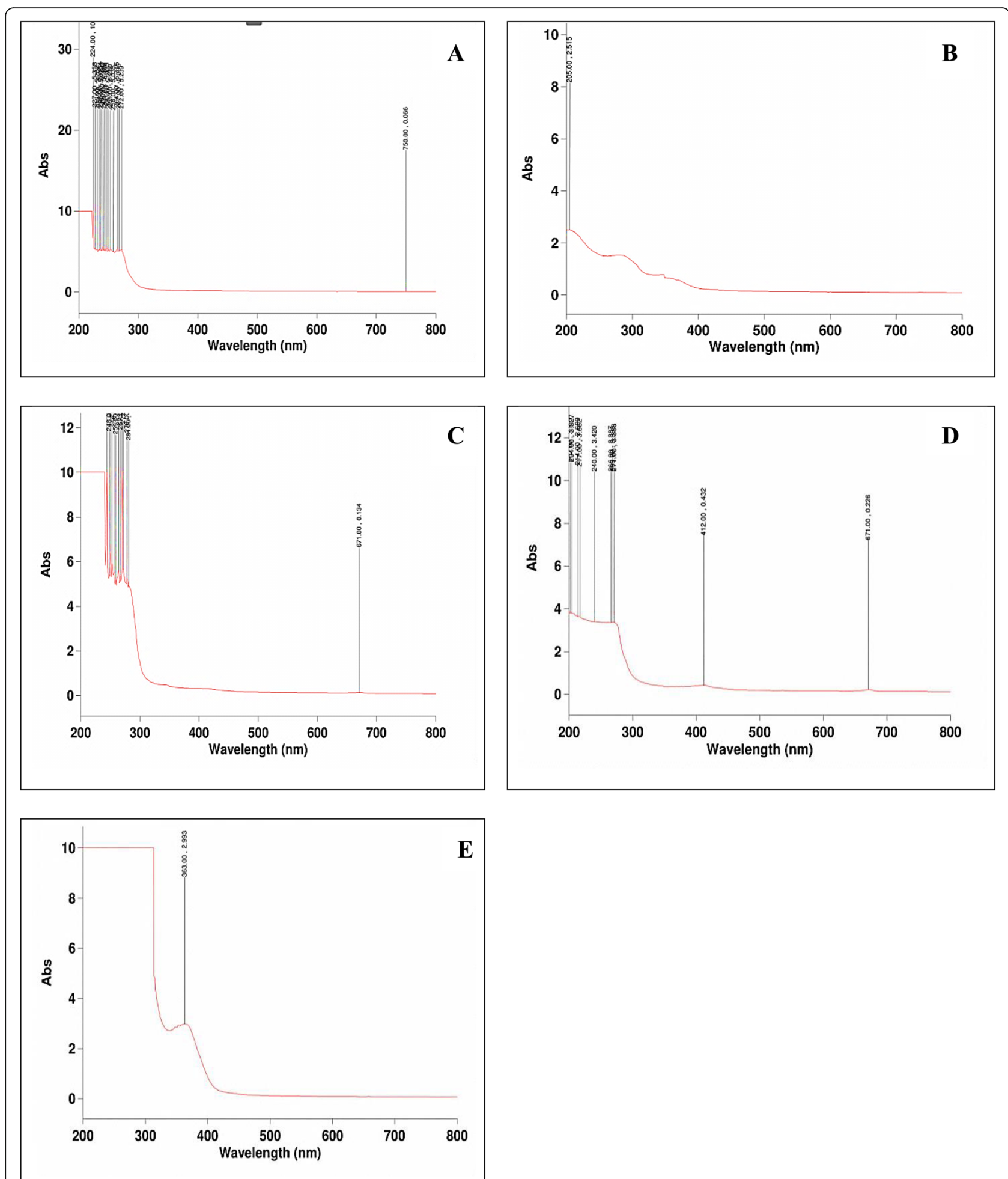

Fig. 6 UV-visible spectra of a Petroleum ether extract of A. occidentale. $\mathbf{b}$ Ethylacetate extract of A. occidentale. $\mathbf{c} n$-hexane extract of $P$. guajava. $\mathbf{d}$ Petroleum ether extract of T. catappa. e Ethylacetate extract of T. catappa

such as L-phenylalanine and its derivative L-phenylalanine benzyl ester are effective agents, even at relatively low concentrations, against $\mathrm{HbS}$ polymerization and have been proposed to be effective therapeutic agents for the management of SCD [72-76]. The improved sickle erythrocyte osmotic stability in samples containing petroleum ether 
extract of T. catappa appeared to suggest that aromatic compounds in petroleum ether extract of T. catappa attenuated $\mathrm{HbS}$ polymerization-induced hemolysis in hypotonic solutions as previously described [35, 59, 70, 71]. From another perspective, the antioxidant phytocomponents from plant materials viz. the anthocyanins, anthraquinones, flavonoids, and antioxidant vitamins (vitamins $\mathrm{C}$ and $\mathrm{E}$ ) generally stabilized membrane systems against molecular and biological agents that compromised membrane integrity [21, 30, 42, 44, 57, 59, 72].

In that regard, the present study showed membrane osmotic stability of sickle erythrocytes were altered in the presence of fractionated leaf extracts of $A$. occidentale, $P$. guajava, and T. catappa, such that the extracts exhibited differential capacities to either stabilize sickle erythrocyte membrane integrity or promote membrane destabilization. Based on the percentile yields of petroleum ether, $n$-hexane, chloroform, and ethylacetate as well as residual aqueous extracts, the results of the present study indicated relatively high content of hydrophilic phytocomponents in leaf extracts of $A$. occidentale, P. guajava, and T. catappa. Nevertheless, the findings of the present investigations did not implicate hydrophilic phytocomponents of $A$. occidentale, P. guajava, and $T$. catappa as agents that promoted sickle erythrocyte stability since, to a large extent, fractions of their residual aqueous extracts promoted membrane destabilization. Rather, hydrophobic fractions of the leaf extracts, namely petroleum ether extract of $A$. occidentale, ethylacetate extract of $A$. occidentale, $n$-hexane extract of $P$. guajava, petroleum ether extract of T. catappa, and ethylacetate extract of T. catappa exhibited comparative high capacity to promote membrane osmotic stability of sickle erythrocytes. The present findings were in agreement with previous reports, in which the authors noted that there was an established positive correlation between hydrophobicity of short-chain aliphatic alcohols and their capacity to alter membrane integrity [77]. For instance, ethylacetate extract of $A$. occidentale contained short-chain aliphatic alcohols, namely 1-hexacosanol, 2hexyl-1-octanol and 4-nonanol 2,6,8-trimethyl-, which further explain, in part, the stabilizing effects of the fraction on sickle erythrocyte membranes subjected to osmotic stress. In concord with the present findings, previous report noted that flavonoids from ethylacetate extract of Lantana camara stabilized normal erythrocyte membrane against osmotic stress [42].

In addition, short-chain aliphatic ester derivatives from the fractionated leaf extracts of A. occidentale, P. guajava, and T. catappa appeared to have promoted sickle erythrocyte osmotic stability as previously reported [77]. Earlier study had posited that hydrophobicity of shortchain aliphatic esters facilitated their integration into the membrane system, eliciting structural rearrangement that promoted membrane stability [77, 78]. In agreement with the present results, previous findings had reported that short-chain aliphatic acids (octadecanoic acid and 16-octadecenoic acid), short-chain aliphatic esters (pentadecanoic acid, 14-methyl ester, and 9-octadecadienoic acid (Z)-, 2, 3-dihydroxypropyl ester), aldehyde ( $\alpha$-campholene aldehyde), nitro compound (cyclohexanespiro$5^{\prime}, 4{ }^{\prime}$-methyl-2' -phenyl-2' -oxazoline), alcohol (borneol), and aliphatic compound ( $\alpha$-phellandrene) in silica gel fractionated aqueous and methanol extracts of Telfairia occidentalis stabilized sickle erythrocyte membrane against osmotic stress and deterred sickling [79].

The present study noted that diisooctyl phthalate and aromatic compounds from ethylacetate extract of $A$. occidentale, in part, stabilized sickle erythrocyte membrane under osmotic stress. The molecular configurations of diisooctyl phthalate and aromatic compounds appeared to have contributed to their stabilizing effect on sickle erythrocyte membrane system. A related study had previously reported that despite inter-species differences in erythrocyte membrane properties, dicarboxylic acids with cyclic hydrocarbons, namely bis (2-ethylhexyl) phthalate, 1,2-cyclohexanedicarboxylic acid, and phthalic acid with a benzene ring significantly stabilized cattle erythrocytes subjected to osmotic pressure due to their wedge-like effect on membrane phospholipids [80].

Additionally, the polarities of antioxidant vitamins and related low molecular weight antioxidants (LMWAs), which protect biological systems against oxidative damage to cellular components, dictate their distribution patterns in cellular regions. For instance, hydrophobic antioxidants such as the tocopherols are restricted to act within the hydrophobic regions of the cell, e.g., biomembrane systems, whereas the hydrophilic antioxidants effect their free radical quenching activities within the aqueous environments of the cell. Accordingly, the current information of cellular distribution of LMWAs suggest that the tendency of phytocomponents from the fractionated leaf extracts of $A$. occidentale, $P$. guajava, and T. catappa to interact and interfere with sickle erythrocyte membrane systems appeared to correlate with hydrophobicity of molecular species of the leaf extracts.

The present study of GC-MS system protocol in conjunction with sickle erythrocyte osmotic stability-guided analysis revealed vast array of hydrophobic phytocomponents, namely short-chain aliphatic esters, methylated aromatic hydrocarbons, cycloalkanes, hexahydro-methanoindene, isoxazole, and short-chain aliphatic carboxylic acids as molecular species from leaf extracts of $A$. occidentale, $P$. guajava, and T. catappa that caused relative osmotic stability of sickle erythrocyte membrane. Furthermore, FT-IR and UV-visible protocols further confirmed the alkanes, aldehydes, esters, conjugated alkenes, aromatic compounds, aromatic ethers, isothiocyanates, primary and tertiary amine, cyanate, alkynes, amide, alcohols, and nitro compounds as phytocomponents from fractionated leaf extracts of $A$. occidentale, $P$. guajava, 
and T. catappa that promoted membrane osmotic stability of sickle erythrocytes.

\section{Conclusion}

The selected groups of fractionated leaf extracts that stabilized sickle erythrocyte membrane against osmotic stress were ethylacetate and petroleum ether extracts of $\mathrm{A}$. occidentale, $n$-hexane extract of $P$. guajava, and petroleum ether and ethylacetate extracts T. catappa. GC-MS, FT-IR, and UV-visible spectrometry systems protocols indicated that short-chain aliphatic esters, methylated aromatic hydrocarbons, cycloalkanes, hexahydro-methanoindene, isoxazole, and short-chain aliphatic carboxylic acids and alkanes were phytocomponents from leaf extracts of $A$. occidentale, $P$. guajava, and T. catappa that stabilized sickle erythrocyte membrane integrity. Other phytocomponents, namely the aldehydes, esters, conjugated alkenes, aromatic compounds, isothiocyanates, primary and tertiary amine, cyanate, alkynes, amide, alcohols, and nitro compounds, were also considered as stabilizers of sickle erythrocyte membrane subjected to osmotic stress.

Specifically, to mention but a few, the combinations of major phytocomponents that stabilized sickle erythrocyte membrane against osmotic stress were hexadecanoic acid, methyl ester, 11-octadecenoic acid, methyl ester, dibutyl phthalate, pentacosane, trans-13-octadecenoic acid, methyl ester, whereas the minor phytocomponents include methyl tetradecanoate, methoxyacetic acid, 3-pentadecyl ester, methyl stearate, hexadecanoic acid, isoxazole, and 4, 5-dimethyl-.

The present research recommend further study on isolation and purification of the phytocomponents suggested, in the present study, to have stabilized osmotic stressed sickle erythrocytes and apply the isolated and purified phytocomponents in membrane osmotic stability studies in vitro in order to establish their membrane stabilizing activity and, possibly, mode of action.

\section{Abbreviations}

EDTA-Na2: Disodium ethylene diamine tetraacetate; FT-IR: Fourier transforminfrared spectroscopy; GC-MS: Gas chromatography-mass spectroscopy; $\mathrm{HbS}$ : Sickle hemoglobin; MCF: Mean corpuscular fragility;

$\mathrm{Na}_{2} \mathrm{HPO}_{4} \cdot 2 \mathrm{H}_{2} \mathrm{O}$ : Disodium hydrogen phosphate dihydrate; $\mathrm{Na}_{2} \mathrm{~S}_{2} \mathrm{O}_{5}$ : Sodium metabisulfite; $\mathrm{NaCl}$ : Sodium chloride; $\mathrm{NaH}_{2} \mathrm{PO}_{4} \cdot 2 \mathrm{H}_{2} \mathrm{O}$ : Sodium dihydrogen phosphate dihydrate; PBS: Phosphate-buffered saline; SCD: Sickle cell disease; UV-visible: Ultra violet-visible spectroscopy

\section{Acknowledgments \\ The authors are grateful for the technical assistance offered by Mr. F.C. Emengaha, Chief Academic Technologist, Department of Medical Biochemistry, College of Medicine and Mr. C.O. Kabiri, Senior Laboratory Technologist, Department of Biochemistry, Faculty of Science, Imo State University, Owerri. The efforts of Mr. Franklyn O. Ohiagu are highly appreciated.}

\section{Authors' contributions}

PCC conceived and designed the research and supervised the laboratory work. PCC prepared the manuscript. PCC/RCE/ABC-A analyzed the data. PCC/ $\mathrm{RCE} / \mathrm{ABC}-\mathrm{A}$ collected the plant samples and carried out the laboratory work.
All authors have approved the manuscript in the present form and gave the permission to submit the manuscript for publication.

\section{Funding}

This work was supported by Imo State University, Owerri, and research grant offered by the Tertiary Education Trust Fund (TETFund) Research Based Interventions of Nigerian Universities. Imo State University, Owerri provided the laboratory space and infrastructures. TETFund provided the financial resources for purchase of laboratory chemicals/reagents and instruments as well as expenses pertaining to transportation and travels. Grant Number: TETFUND/DRSS/UNIV/OWERRI/2015/5RP VOL 1 (7).

Availability of data and materials

All the data generated and analyzed during the study are included in the main manuscript.

\section{Ethics approval and consent to participate}

Collection of the blood samples was in accordance with the ethical principles that have their origins in the October 2008 Declaration of Helsinki. The present study was approved by the Ethical Committee for Research, Department of Biochemistry, Imo State University, Owerri, Nigeria. Ethics Approval Number: ODVC/REN/544/19. All the participants filled and signed Informed Consent Form.

\section{Consent for publication}

Not applicable.

\section{Competing interests}

The authors declare that they have no competing interests.

Received: 29 October 2019 Accepted: 16 December 2019

Published online: 03 March 2020

\section{References}

1. Mota ML, Thomas G, BarbosA-Eilho JM (1985) Anti-inflammatory actions of tannins isolated from the bark of Anacardium occidentale L. J Ethanopharmacol. 13:289-300. https://doi.org/10.1016/0378-8741(85)90074-1

2. Kudi AC, Umoh JU, Eduvic LO, Getu J (1999) Screening of some Nigerian medicinal plants for antibacterial activity. J Ethanopharmacol. 67:225-228. https://doi.org/https://doi.org/10.1016/s0378-8741(98)00214-1

3. Konan NA, Bacchi EM, Lincopan N, Varela SD, Varanda EA (2007) Acute, subacute toxicity and genotoxic effect of a hydroethanolic extract of the cashew (Anacardium occidentale L.). J Ethnopharmacol. 110:30-38. https:// doi.org/https://doi.org/10.1016/j.jep.2006.08.033

4. Arya R, Babu V, llyas M, Nassim KT (1989) Phytochemical examination of the leaves of Anacardium occidentale. J Indian Chem Soc. 66:67-68

5. Cocon JM (1988) Food Toxicology, Principles and Concepts. Marcel Dekker, New York, pp 313-319 https://doi.org/10.1002/food.19880321032

6. Laurens A, Mboup S, Giono-Barber P, David-Prince M (1982) Etude de l'action antibactedenne d'extraits d'Anacardium occidentale L. Ann Pharmaceut Francaises 40:143-146 https://journals.openedition.org/ vertigo/18861

7. Maia JGS, Andrade EHA, Zoghbi MGB (2000) Volatile constituents of the leaves, fruits and flowers of Cashew (Anacardium occidentale L.). J Food Comp Anal. 13:227-232 https://doi.org/10.1006/jfca.2000.0894

8. Desai D, Raorane C, Patil S, Gadgil R, Patkar D (2017) Anacardium occidentale: fountain of phytochemicals: The qualitative profiling. World J Pharmaceut Res. 6:585-592 https://doi.org/10.20959/wjpr20175-7822

9. Lozoya X, Becerril G, Martínez M (1990) Model of intraluminal perfusion of the guinea pig ileum in vitro in the study of the antidiarrheal properties of the guava (Psidium guajava). Arch Invest Med (Mexico). 21:155-162 https:// www.ncbi.nlm.nih.gov/pubmed/2103704

10. Coutino-Rodriguez R, Hernandez-Cruz P, Giles-Rios H (2001) Lectin in fruits having gastrointestinal activity: their participation in the hemagglutinating property of Escherichia coli 0157:H7. Arch Med Res. 32:251-257 https://doi. org/10.1016/S0188-4409(01)00287-9

11. Rahman MM, Ahmad SH, Mohamed MTM, Rahman MZA (2014) Antimicrobial compounds from leaf extracts of Jatropha curcas, Psidium guajava, and Andrographis paniculata. Sci World J Article ID 635240:8. https://doi.org/10.1155/2014/635240 
12. Akins RA (2005) An update on antifungal targets and mechanisms of resistance in Candida albicans. J Med Mycol. 43:285-318. https://doi.org/ https://doi.org/10.1080/13693780500138971

13. Singh RB, Rastogi SS, Singh NK, Ghosh S, Niaz MA (1992) Effects of guava intake on serum total and high-density lipoprotein cholesterol levels and on systemic blood pressure. Am J Cardiol. 70:1287-1291. https://doi.org/https:// doi.org/10.1016/0002-9149(92)90763-o

14. Singh RB, Rastogi SS, Singh NK, Ghosh S, Gupta S (1993) Can guava fruit intake decrease blood pressure and blood lipids. J Human Hypertens. 7:3338 https://www.ncbi.nlm.nih.gov/pubmed/8383769

15. Morales MA, Tortoriello J, Meckes M, Paz D, Lozoya X (1994) Calcium antagonist effect of quercetin and its relation with the spasmolytic properties of Psidium guajava L. Arch Med Res. 25:17-21 https://www.ncbi. nlm.nih.gov/pubmed/8019109

16. Tona L, Kambu K, Mesia K, Cimanga K, Apers S, de Bruyne T (1999) Biological screening of traditional preparations from some medicinal plants used as antidiarrhoeal in Kinshasa, Congo. Phytomed. 6:59-66. https://doi. org/https://doi.org/10.1016/S0944-7113(99)80036-1

17. Block G, Patterson B, Subar A (1992) Fruit, vegetables, and cancer prevention: A review of the epidemiological evidence. Nutr Cancer. 18:1-29. https://doi.org/https://doi.org/10.1080/01635589209514201

18. Steinmetz KA, Potter JD (1996) Vegetables, fruit, and cancer prevention: a review. J Am Dietetics Assoc. 96:1027-1039. https://doi.org/https://doi.org/ 10.1016/S0002-8223(96)00273-8

19. Masuda T, Yonemori S, Oyama Y, Takeda Y, Tanaka T, Andoh T, Shinohara A, Nakata M (1999) Evaluation of the antioxidant activity of environmental plants: Activity of the leaf extracts from seashore plants. J Agric Food Chem. 47:1749-1754. https://doi.org/https://doi.org/10.1021/jf980864s

20. Knekt $P$, Kumpulainen J, Jarvinen $R$, Rissanen $H$, Heliovaara M, Reunanen A (2002) Flavonoid intake and risk of chronic diseases. Am J Clin Nutr. 76:560568. https://doi.org/https://doi.org/10.1093/ajcn/76.3.560

21. Chikezie PC, Ibegbulem CO, Mbagwu FN (2015) Bioactive principles from medicinal plants. Res J Phytochem. 9:88-115 https://doi.org/10.3923/rjphyto. 2015.88.115

22. Terças AG, Monteiro AS, Moffa EB, dos Santos JRA, de Sousa EM (2017) Phytochemical characterization of Terminalia catappa Linn extracts and their antifungal activities against Candida spp. Front Microbiol. 8:1-13. https://doi. org/https://doi.org/10.3389/fmicb.2017.00595

23. Nagappa AN, Thakurdesai PA, Venkat Rao N, Singh J (2003) Anti-diabetic activity of Terminalia catappa Linn fruits. J Ethnopharmacol. 88:45-50. https://doi.org/https://doi.org/10.1016/s0378-8741(03)00208-3

24. Chikezie PC (2011) Sodium metabisulphite induced polymerization of sickle cell haemoglobin $(\mathrm{HbS})$ incubated in extracts of three medicinal plants (Anacardium occidentale, Psidium guajava and Terminalia catappa). Pharmacogn Mag. 7:126-132 https://doi.org/10.4103/0973-1296.80670

25. Oyewale JO, Ajibade HA (1990) The osmotic fragility of erythrocytes of turkeys of two age groups. Vet Arch. 60:43-48

26. Chikezie PC, Uwakwe AA (2011) Membrane stability of sickle erythrocytes incubated in extracts of three medicinal plants: Anacardium occidentale, Psidium guajava and Terminalia catappa. Pharmacogn Mag 7:121-125 https://doi.org/10.4103/0973.1296.80669

27. Walski T, Chludzinska L, Komorowska M, Witkiewicz W (2014) Individual osmotic fragility distribution: A new parameter for determination of the osmotic properties of human red blood cells. BioMed Res Int Article ID 162102:6. https://doi.org/10.1155/2014/162102

28. King MJ, Zanella A (2013) Hereditary red cell membrane disorders and laboratory diagnostic testing. Int J Lab Hematol. 35:237-243 https://doi.org/ 10.1111/ijlh.12070

29. Huisjes R, Solinge WW, Levin MD, Wijk R, Riedl JA (2017) Digital microscopy as a screening tool for the diagnosis of hereditary hemolytic anemia. Int J Lab Hematol. 40:159-168 https://doi.org/10.1111/ijlh.12758

30. Igbokwe NA (2018) A review of the factors that influence erythrocyte osmotic fragility. Sokoto J Vet Sci. 16:1-23 https://doi.org/10.4314/sokjvs.v16i4.1

31. Emilse LAM, Cecilia H, María TM, Eugenia MM, Alicia IB, Lazarte SS (2018) Cryohemolysis, erythrocyte osmotic fragility, and supplementary hematimetric indices in the diagnosis of hereditary spherocytosis. Blood Res. 53:10-17 https://doi.org/10.5045/br.2018.53.1.10

32. Rab MAE, van Oirschot BA, Bos J, Merkx TH, van Wese ACW, Abdulmalik O et al (2019) Rapid and reproducible characterization of sickling during automated deoxygenation in sickle cell disease patients. Am J Hematol. 2019:1-10 https://doi.org/10.1002/ajh.25443
33. Oyewole O, Malomo S, Adebayo J (2008) Comparative studies on antisickling properties of thiocyanate, tellurite and hydroxyurea. Pak J Med Sci. 24:18 https://www.pjms.com.pk/issues/janmar08/pdf/antisickling.pdf

34. Uwakwe AA, Nwaoguikpe RN (2008) In vitro antisickling effects of Xylopia aéthiopica and Monodora myristica. J Med Plant Res. 2:119-124 https:// academicjournals.org/article/article1380378586_Uwakwe\%20and\%2 oNwaoguikpe.pdf

35. Nurain IO, Bewaji CO, Johnson JS, Davenport RD, Zhang Y (2017) Potential of three ethnomedicinal plants as antisickling agents. Mol Pharm. 14:172182 https://doi.org/10.1021/acs.molpharmaceut.6b00767

36. Makani J, Ofori-Acquah SF, Nnodu O, Wonkam A, Ohene-Frempong K (2013) Sickle cell disease: New opportunities and challenges in Africa. Sci World J Article ID 193252:16. https://doi.org/10.1155/2013/193252

37. Dash BP, Archana Y, Satapathy N, Naik SK (2013) Search for antisickling agents from plants. Pharmacogn Rev. 7:53-60 https://doi.org/10.4103/09737847.112849

38. Folashade $\mathrm{KO}$, Omoregie EH (2013) Chemical constituents and biological activity of medicinal plants used for the management of sickle cell disease - A review. J Med Plant Res. 7:3452-3476 https://doi.org/10.5897/JMPR2013.5333x

39. George A, Pushkaran S, Konstantinidis DG, Koochaki S, Malik P, Mohandas N, et al., (2013) Erythrocyte NADPH oxidase activity modulated by Rac GTPases, PKC, and plasma cytokines contributes to oxidative stress in sickle cell disease. Blood. 121:2099-20107. https://doi.org/https://doi.org/10.1182/ blood-2012-07-441188

40. Voskou S, Aslan M, Fanis P, Phylactides M, Kleanthous M (2015) Oxidative stress in $\beta$-thalassaemia and sickle cell disease. Redox Biol. 6:226-239 https://doi.org/10.1016/j.redox.2015.07.018

41. Manafa PO, Okocha CE, Aneke JC, Obiano U, Ibeh NC et al (2017) Low serum glutathione-S-transferase activity and vitamin E levels do not correlate with disease severity in steady state adults with sickle cell anemia. J Appl Hematol. 8:110-115 https://doi.org/10.4103/joah.joah_22_17

42. Oyedapo OO, Akinpelu BA, Akinwunmi KF, Adeyinka MO, Sipeolu FO (2010) Red blood cell membrane stabilizing potentials of extracts of Lantana camara and its fractions. Int J Plant Physiol Biochem. 2:46-51 http://www.academicjournals.org/ app/webroot/article/article1380020463_Oyedapo\%20et\%20al.pdf

43. Chikezie PC, Akuwudike AR, Chikezie CM (2012) Membrane stability and methaemoglobin content of human erythrocytes incubated in aqueous leaf extract of Nicotiana tabacum product. Free Radic Antioxid. 2:56-61 https:// doi.org/10.5530/ax.2012.4.10

44. Anosike CA, Igboegwu ON, Nwodo OFC (2019) Antioxidant properties and membrane stabilization effects of methanol extract of Mucuna pruriens leaves on normal and sickle erythrocytes. J Tradit Compl Med. 9:278-284 https://doi.org/10.1016/j.jtcme.2017.08.002

45. Singh P, Andola HC, Rawat MSM, Pant GJN, Purohit VK (2011) Fourier transform-infrared (FT-IR) spectroscopy: An overview. Res J Med Plant. 5: 127-135 https://doi.org/10.3923/rjmp.2011.127.135

46. Sasidharan S, Chen Y, Saravanan D, Sundram KM, Yoga LL (2011) Extraction, isolation and characterization of bioactive compounds from plants' extracts. Afr J Tradit Compl Altern Med. 8:1-10 https://www.ncbi.nlm.nih.gov/pmc/ articles/PMC3218439/pdf/AJT0801-0001.pdf

47. Karayil S, Chandran KPS, Sudeesh PS, Veraiah K (2014) Isolation and structural elucidation of novel bioactive molecule-Coumarin from traditionally used medicinal plant-Ceropegia juncea (Roxb.). IOSR. J Pharm Biol Sci. 9:19-22 https://doi.org/10.9790/3008-09321922

48. Rašković A, Pavlović N, Kvrgić M, Sudji J, Mitić G, Čapo I (2015) Effects of pharmaceutical formulations containing thyme on carbon tetrachlorideinduced liver injury in rats. BMC Compl Altern Med. 15:442-411. https://doi. org/10.1186/s12906-015-0966-z

49. Altemimi A, Lakhssassi N, Baharlouei A, Watson DG, Lightfoot DA (2017) Phytochemicals: extraction, isolation, and identification of bioactive compounds from plant extracts. Plants. 6:42-23. https://doi.org/10.3390/plants6040042

50. Ojiako AO, Chikezie PC, Ogbuji CA (2015) Histopathological studies of renal and hepatic tissues of hyperglycemic rats administered traditional herbal formulations. Int J Green Pharm. 9:184-191 https://doi.org/10.4103/0973-8258.161237

51. Okoye TC, Akah PA, Okoli CO, Ezike AC, Mbaoji FN (2010) Antimicrobial and antispasmodic activity of leaf extract and fractions of Stachytarpheta cayennensis. Asian Pac J Trop Med. 2010:189-192 https://doi.org/10.1016/ S1995-7645(10)60006-5

52. Yamamoto A, Saito N, Yamauchi Y, Takeda M, Ueki S, Itoga M et al (2014) Flow cytometric analysis of red blood cell osmotic fragility. J Lab Autom. 19: 483-487 https://doi.org/10.1177/2211068214532254 
53. Bain B, Bates I, Laffan M (2011) Dacie and Lewis practical haematology, 11th edn. Elsevier Churchill Livingstone, Amsterdam https://www.academia. edu/36985667/Dacie_and_Lewis_Practical_Haematology

54. Ighodaro OM, Akinloye OA, Ugbaja RN, Omotainse SO, Faokunla O (2016) FT-IR analysis of Sapium ellipticum (Hochst) pax ethanol leaf extract and its inhibitory effects on pancreatic a-amylase and intestinal a-glucosidase activities in vitro. Egypt J Basic Appl Sci. 3:343-349 https://doi.org/10.1016/j. ejbas.2016.09.003

55. Hemavathy A, Shanthi P, Sowndharya C, Thiripura SS, Priyadharshni K (2019) Extraction and isolation of bioactive compounds from a therapeutic medicinal plant - Wrightia tinctoria (Roxb.) R. Br Int J Pharmacogn Phytochem Res 11:199-204 http://impactfactor.org/PDF/IJPPR/11/IJPPR. Vol11.Issue3.Article15.pdf

56. Sampaio KL, Garruti DS, Franco MRB, Janzantti NS, da Silva MAP (2011) Aroma volatiles recovered in the water phase of cashew apple (Anacardium occidentale L.) juice during concentration. J Sci Food Agric. 91:1801-1809 https://doi.org/10.1002/jsfa.4385

57. de Freitas MV, Netto RCM, Huss JCC, de Souza TMT, Costa JO et al (2008) Influence of aqueous crude extracts of medicinal plants on the osmotic stability of human erythrocytes. Toxicol In Vitro. 22:219-224 https://doi.org/ 10.1016/j.tiv.2007.07.010

58. Chikezie PC, Uwakwe AA, Monago CC (2009) Studies of human HbAA erythrocytes osmotic fragility index of non malarious blood in the presence of five antimalarial drugs. J Cell Ani Biol. 3:039-043

59. Nguelewou LLF, Biapa NPC, Chetcha B, Kengne FC, Tankeu NF, Nanfack P et al (2019) In vitro antisickling and antioxidant effects of hydro-ethanolic extracts of Theobroma cacao (sterculiaceae) from west and centre regions in Cameroon. J Pharm Sci Innov. 8:79-86 https://doi.org/10.7897/2277-4572.083131

60. He J, Lin J, Li J, Zhang J-H, Sun X-M et al (2008) Dual effects of Ginkgo biloba leaf extract on human red blood cells. Basic Clin Pharmacol Toxicol. 104:138-144 https://doi.org/10.1111/j.1742-7843.2008.00354.x

61. Mousinho KC, Correia MBL, da Silva JO, Magnata SLP, de Souza IA, Catanho MTJA (2008) Effect of the extract of Ricinus communis L. on the osmotic fragility, labeling of red blood cells with Technetium-99m and morphology of the cells. Braz Arch Biol Technol. 51:1139-1146 https://doi.org/10.1590/ S1516-89132008000600008

62. Alnakshbandi AA (2015) Aminoglycosides induce fragility of human red cell membrane: An in vitro study. Indian J Pharmacol. 47:114-116 https://doi. org/10.4103/0253-7613.150375

63. Casagrande JC, Macorini LF, Antunes KA, Santos UP, Campos JF et al (2014) Antioxidant and cytotoxic activity of hydroethanolic extract from Jacaranda decurrens leaves. PLoS One. 9:e112748 https://doi.org/10.1371/journal.pone. 0112748

64. Figueirêdo Júnior EC, Costa BP, Freire JCP, Melo WOS, Pessôa HLF et al (2019) Use of erythrocytes in cytotoxicity and toxicity assays of medicinal plant extracts: analysis of their application and bibliometric study. Boletín Latinoamericano Y Del Caribe De Plantas Medicinales Y Aromáticas. 18:359377 https://doi.org/10.35588/blacpma.19.18.4.23

65. Jarolim P, Lahav M, Liu S-C, Palek J (1990) Effect of hemoglobin oxidation products on the stability of red cell membrane skeletons and the associations of skeletal proteins: correlation with a release of hemin. Blood. 76:2125-2131 https://doi.org/10.1182/blood.V76.10.2125. bloodjournal76102125

66. Rank BH, Carlsson J, Hebbel RP (1985) Abnormal redox status of membraneprotein thiols in sickle erythrocytes. J Clin Invest. 75:1531-1537 https://doi. org/10.1172/JCl111857

67. Hebbel RP (1991) Beyond hemoglobin polymerization: the red blood cell membrane and sickle disease pathophysiology. Blood. 77:214-237 https:// doi.org/10.1182/blood.V77.2.214.bloodjournal772214

68. Dong C, Chadwick RS, Schechter AN (1992) Influence of sickle hemoglobin polymerization and membrane properties on deformability of sickle erythrocytes in the microcirculation. Biophys J. 63:774-783.

69. Fisseha D, Katiyar VK (2012) Analysis of mechanical behavior of red cell membrane in sickle cell disease. Appl Math. 2:40-46 https://doi.org/10.5923/ j.am.20120202.08

70. Park S, Hayes BL, Marankan F, Mulhearn DC, Wanna L, et al., (2003) Regioselective covalent modification of hemoglobin in search of antisickling agents. J Med Chem. 46:936-953. https://doi.org/https://doi.org/10.1021/jm020361k

71. Safo MK, Kato GJ (2014) Therapeutic strategies to alter the oxygen affinity of sickle haemoglobin. Haematol Oncol Clin N Am. 28:217 https://doi.org/10. 1016/j.hoc.2013.11.001
72. Imaga NA (2013) Phytomedicines and nutraceuticals: alternative therapeutics for sickle cell anemia. Sci World J Article ID 269659:12. https:// doi.org/10.1155/2013/269659

73. Rumen NM (1975) Inhibition of sickling in erythrocytes by amino acids. Blood. 45:45-48 https://doi.org/10.1182/blood.V45.1.45.bloodjournal45145

74. Noguchi CT, Schechter AN (1981) Intracellular polymerization of sickle haemoglobin and its relevance to sickle cell disease. J Am Soc Haematol. 5: 1057-1068 www.bloodjournal.org

75. Noguchi CT, Schechter AN (1978) Inhibition of sickle hemoglobin gelation by amino acids and related compounds. Biochem. 17:5455-5459 https://doi. org/10.1021/bi00618a020

76. Acquaye CTA, Young JD, Ellory JC, Gorecki M, Wilcher M (1982) Mode of transport and possible mechanism of action of L-phenylalanine benzyl ester as an antisickling agent. Biochim Biophys Acta. 693:407-416 https://doi.org/ 10.1016/0005-2736(82)90448-5

77. Mckarns SC, Hansch C, Caldwell WS, Morgan WT, Moore S, Doolittle DJ (1997) Correlation between hydrophobicity of short-chain aliphatic alcohols and their ability to alter plasma membrane integrity. Fundam Appl Toxicol. 36:62-70. https://doi.org/https://doi.org/10.1006/faat.1996.2252

78. Zavodnik IB, Lapshina EA, Palecz D, Bryszewska M (1996) The effects of palmitate on human erythrocyte membrane potential and osmotic stability. Scand J Clin Lab Invest. 56:401-407. https://doi.org/https://doi.org/10.3109/ 00365519609088794

79. Atabo S, Umar IA, James DB, Mamman Al (2016) Sickled erythrocytes reversal and membrane stabilizing compounds in Telfairia occidentalis. Sci Article ID 1568061:7. https://doi.org/10.1155/2016/1568061

80. Mineo H, Moriyoshi M (2019) Carboxylic acids with certain molecular structures decrease osmotic fragility against osmotic pressure in cattle erythrocytes in vitro: appearance of a wedge-like effect similar to RBCs in other animal species. Biochem Pharmacol. 8:264-212. https://doi.org/10. 4172/2167-0501.1000264

\section{Publisher's Note}

Springer Nature remains neutral with regard to jurisdictional claims in published maps and institutional affiliations.

\section{Submit your manuscript to a SpringerOpen ${ }^{\odot}$ journal and benefit from:}

- Convenient online submission

- Rigorous peer review

- Open access: articles freely available online

- High visibility within the field

- Retaining the copyright to your article

Submit your next manuscript at $>$ springeropen.com 